\title{
Fiscal policy and economic growth
}

\section{An empirical investigation*}

\author{
William Easterly \\ World Bank, Washington, DC 20433, USA
}

\section{Sergio Rebelo ${ }^{\dagger}$}

University of Rochester, Rochester, NY 14627, USA

Received March 1993, final version received September 1993

\begin{abstract}
This paper describes the empirical regularities relating fiscal policy variables, the level of development, and the rate of growth. We employ historical data, recent cross-section data, and newly constructed public investment series. Our main findings are: (i) there is a strong association between the development level and the fiscal structure: poor countries rely heavily on international trade taxes, while income taxes are only important in developed economies; (ii) fiscal policy is influenced by the scale of the economy, measured by its population; (iii) investment in transport and communication is consistently correlated with growth; (iv) the effects of taxation are difficult to isolate empirically.
\end{abstract}

Key words: Growth; Development; Fiscal policy

JEL classification: $\mathrm{O} 40 ; \mathrm{E} 62$

\section{Introduction}

If you ask an economist to explain the growth performance of a particular country he is likely to mention fiscal policy as being an important growth

Correspondence to: Sergio Rebelo, Department of Economics, University of Rochester, Rochester, NY 14627, USA.

*We wish to thank George Clarke, Rui Albuquerque, and Piyabha Kongsamut for their dedicated research assistance. We benefited from the comments of Robert Barro, Oded Galor, Robert King, Larry Kotlikoff, Ross Levine, Charles Plosser, Jonathan Skinner, Nicholas Stern, Nancy Stokey, Guido Tabellini, and Vito Tanzi. We also benefited from feedback provided by seminar participants at Boston College, Brown, Georgetown, Harvard, MIT, Northwestern, NYU, Pennsylvania, Virginia, and UCL $\Lambda$, and by participants at the Conferences on Economic Growth in Estoril, Portugal, in January 1993, and at the World Bank, in February 1993. The usual disclaimer applies.

${ }^{\dagger}$ Also affiliated with the Portuguese Catholic University, Lisbon, the Bank of Portugal, Lisbon, and the NBER, Cambridge, Massachusetts. 
determinant. This deep-seeded belief that taxation, public investment, and other aspects of fiscal policy can contribute to growth miracles as well as to enduring stagnation has been articulated in the context of growth models during the past three decades.

Growth models, both old and new, feature simple channels that link certain taxes to the rate of growth. Increases in income taxes, for example, lower the net rate of return to private investment, making investment activities less attractive and lowering the rate of growth. It is hard to think of an influence on the private real rate of return and on the growth rate that is more direct than that of income taxes. If these do not affect the rate of growth, what does?

Unfortunately, the empirical evidence that is currently available to shed light of the importance of fiscal policy in determining growth is sparse. ${ }^{1}$ This sparseness reflects the difficulties involved in measuring the variables that theory predicts to be important growth determinants: marginal tax rates and subsidies, and levels of public investment.

Our goal in this paper is to provide a comprehensive summary of the statistical association between measures of fiscal policy, the level of development, and the rate of growth using standard data sources combined with newly created data for public investment. We will document the empirical regularities that emerge in a broad cross-section of countries with data for the period 1970 to 1988 as well those associated with the long-run historical data that is available for a small set of countries. There is substantial measurement error in both of these data sets, but there is also information.

The next section of the paper reviews briefly the theoretical literature on fiscal policy and growth. Our empirical investigation starts in section 3 which uses fiscal data for the period $1970-1988$ in the context of cross-section regressions made popular by the work of Barro (1991). We find that the high correlation between many fiscal variables and the level of income in the beginning of the period makes it difficult to isolate the effect of fiscal policy in the context of the Barro regression. This correlation with initial income leads us to study in section 4 whether fiscal policy is endogenous in the sense of being related to characteristics such as the level of development and the overall scale of the economy.

Our empirical findings are summarized by the following list of ten stylized facts. We use the term 'cross-section' to refer to our cross-section data set of about 100 countries for the period 1970-1988. The term 'historical data' refers to our panel of annual data for 28 countries comprising the period from 1870 to 1988 .

\footnotetext{
${ }^{2}$ Prior empirical analyses of the relation between fiscal policy and growth include Garcia-Mila (1987), Grier and Tullock (1989), Koester and Kormendi (1989), Plosser (1992), and Engen and Skinner (1992).
} 
(1) The share of public investment in transport and communication is robustly correlated with growth in our cross-section when we control for the slew of variables standard in cross-section studies. This partial correlation survives when we instrument for this variable (although the resulting coefficient is implausibly high).

(2) The government's budget surplus is also consistently correlated with growth and private investment in our cross-section.

(3) The link between most other fiscal variables and growth is statistically fragile. The statistical significance of these variables in a cross-section regression context depends heavily on what other control variables are included in the regression. This fragility is partly a result of multicollinearity. Fiscal variables tend to be highly correlated with the level of income in the beginning of the period and are highly correlated among themselves (countries that have higher taxes also have higher spending).

(4) Government revenue/GDP rises with per capita income (Wagner's Law) in both the cross-section and the historical data sets.

(5) In both of our data sets, we observe that as income rises, international trade taxes fall as a share of government revenue, while the share of income taxes rises.

(6) In our cross-section higher income countries have relatively higher government health expenditures and larger social security programs.

(7) The choice of fiscal instruments seems to be related to the scale of the economy. In both of our data sets we find that as population increases the share of trade taxes in revenue falls and the share of income taxes rises. This relation continues to hold if we control for income and for the trade share.

(8) Our cross-section data shows that high population countries spend more on defense and less on transport and communication.

(9) High levels of inequality in income distribution, observed prior to 1970 , were associated with higher levels of publicly provided education in the period from 1970 to 1988.

(10) There are no significant differences in the fiscal policies adopted by democracies and nondemocracies once we control for the level of income.

\section{The theoretical predictions}

The development of the neoclassical model provided public finance students with a theoretical construct suitable to think about the growth effects of fiscal policy. Researchers such as Sato (1967), Krzyzaniak (1967), and Feldstein (1974) used versions of the Solow (1956) model to study the dynamic impact of taxation. More recently, Chamley (1986) and Judd (1985), among others, have used the neoclassical growth model with an endogenous savings rate developed by Cass (1965) and Koopmans (1965) as a laboratory to study fiscal policy. 
Diamond's (1965) overlapping generations version of the neoclassical model has also been extensively used - by Summers (1981), Auerbach and Kotlikoff (1987), and others - to examine the dynamic effects of fiscal policy.

Since in the neoclassical model steady state growth is driven by exogenous factors - the dynamics of population and of technological progress - fiscal policy can only affect the rate of growth during the transition to the steady state. Because of this fact, the conventional wisdom based on the neoclassical model has been that differences in tax systems and in debt and expenditure policy can be important determinants of the level of output but are unlikely to have an important effect on the rate of growth. ${ }^{2}$

This conventional wisdom contrasts with the predictions of Eaton's (1981) stochastic growth model, which features a linear production function, as well as with those of more recent 'endogenous growth' models [e.g., a version of Romer's (1986) model that admits steady state growth, the economies with convex technologies explored by Jones and Manuelli (1990) and Rebelo (1991), and the 'lab-equipment model' of Rivera-Batiz and Romer (1991)]. In these models fiscal policy can be one of the main determinants of the observed differences in growth experiences.

'Endogenous growth' models tend to transform the temporary growth effects of fiscal policy implied by the neoclassical model into permanent growth effects. The strength of these effects varies, however, from model to model, depending heavily on the elasticity of labor supply and on aspects of the technology to accumulate human capital and to create new goods about which very little is currently known [see Jones, Manuelli, and Rossi (1993) and Stokey and Rebelo (1993)].

In order to isolate the effect of each fiscal instrument it is standard in public finance to assume that the impact of a change in a fiscal variable on government revenue or expenditure is compensated with lump sum taxes or subsidies. We describe below the long-run effect of permanent changes in various fiscal instruments under this assumption.

Most growth models predict that taxes on investment and income have a detrimental effect on growth. These taxes affect the rate of growth through a simple, direct, channel: they reduce the private returns to accumulation. But not all taxes affect the rate of growth. In models with exogenous labor supply the growth rate is immune to the level of consumption taxes; these taxes do not distort the relative price of consumption today versus tomorrow, leaving unaffected the incentive to accumulate capital.

The effect of an increase in government consumption should also be nil if we view this component of public expenditures as leaving the productivity of the

\footnotetext{
${ }^{2}$ In the standard neoclassical model with a conventional value for the share of capital in output the transitional dynamics can only be important if the real interest rate takes on implausibly high values [King and Rebelo (1993)].
} 
private sector unaffected. In contrast, the effect of public investment should be positive since this type of activity is likely to enhance the productivity of the private sector [Aschauer (1989), Barro (1990)].

When we change more than one instrument at a time we get a combination of these various partial effects. For example, the effects of an increase in government investment financed by income taxes is ambiguous [see Barro (1990)].

The effects of government deficits are more complex. In overlapping generations models government deficits tend to reduce the savings rate and the rate of growth [see Alogoskoufis and Ploeg (1991)]. In infinite horizon models the effects of deficits depend on the variables that have to be adjusted in the future to compensate for the deficits. If a higher deficit today will later be compensated by higher consumption or income taxes the rate of growth will decline.

In the empirical analysis that we describe in the next section we pay particular attention to two of the strongest predictions of growth models: that high income taxes lower the rate of growth and that high public spending on infrastructure investment raises growth.

\section{Recent cross-section evidence}

Our cross-section data set comprises the period 1970-1988 and combines information from five sources: Summers and Heston (1991), Barro and Wolf (1989), the Government Financial Statistics (GFS), the International Financial Statistics (IFS), and Easterly, Rodriguez, and Schmidt-Hebbel (1993). Later on in this section we also explore new data for public investment that we created using information contained in World Bank reports.

GFS, which is our main source of fiscal data suffers from two relevant shortcomings: (i) it includes only Central government activities and thus excludes local governments and public enterprises (although it includes transfers from the Central government to both local governments and public enterprises), and (ii) for some years and some countries the GFS statistics are based on budget data.

A complete list of the fiscal variables that we employed, as well as their sample means and stanciard deviations, is included in the appendix. Unless we state otherwise all fiscal variables are expressed as percentages of GDP and correspond to averages over the 1970-1988 period. We will explore mainly the cross-section dimension of the data because Easterly, Kremer, Pritchett, and Summers (1993) show that the variability over time of country characteristics adds little explanatory power.

\subsection{Measuring marginal tax rates}

The most important obstacle to an empirical investigation of the effects of fiscal policy on growth is that marginal tax rates and subsidies - which are the 
relevant variables according to theory - are not observable. To compute marginal income tax rates one would ideally use the methodology of Barro and Sahasakul (1983). However, this requires information on individual incomes and taxes that is currently publicly available only for a small set of developed countries. We have explored four approaches to measuring tax rates, each with its own problems. ${ }^{3}$

Statutory tax rates on income are available for a cross-section of developing countries [see Sicat and Virmani (1988)]. We included these tax rates in our data set, but given that tax evasion is an important phenomenon in LDC's, we suspect that these rates grossly overestimate the distortions associated with income taxation. Colombia is a representative example of tax evasion. Its personal income tax in 1984 allowed for very few deductions and credits and featured marginal tax rates that ranged between $7 \%$ and $49 \%$. Yet, the revenue collected in 1984 represented only $1.75 \%$ of personal income.

We use the revenue from different types of taxes expressed as a fraction of GDP as a measure of the tax distortions. In the case of the income tax this would only correspond to the marginal tax rate on income if the tax were proportional. Even stronger assumptions are needed to guarantee that the fraction of revenue in GDP corresponds to marginal tax rates in the case of taxes on investment and on consumption. For this reason, we also constructed tax rates as the ratio of a specific type of revenue to the corresponding tax base (e.g., trade tax revenue/total trade or personal income tax/personal income).

We used the income-weighted marginal income tax rates computed in Easterly and Rebelo (1993), where we employ a method that combines information on the lowest and the highest statutory tax rates, on the level of income for which taxes are zero, on the distribution of income, and on the income tax revenue collected.

Finally, we computed 'marginal' taxes rates by regressing the revenue from each type of tax on its tax base, as in Koester and Kormendi (1989). Unfortunately, the results of some of these regressions tend to vary significantly with the sample period employed since a significant number of LDCs reformed their tax system during the $1980 \mathrm{~s}^{4}{ }^{4}$ This instability is also problematic for our ratios of revenue to the tax base or to GDP.

While the statutory tax rates tend to overestimate the distortion effects of taxation, the three types of measures discussed above tend to underestimate

\footnotetext{
${ }^{3}$ We also explored the possibility of computing statutory effective marginal tax rates on capital income along the lines of King and Fullerton (1984), taking advantage of the software developed by Dunn and Pellechio (1990) which can produce effective marginal tax rates for various developing countries. We found, as is common in this literature, that the effective marginal tax rates were very sensitive to the mix of assets involved in the project as well as to the choice of financing arrangements.

${ }^{4}$ Countries for which the regression coefficients are unstable generally have negative slope coefficients. We discarded those countries from our sample and retained only the ones with positive 'marginal' tax rates.
} 
Table 1

Simple correlations of fiscal variables with per capita growth rate, 1970-88.

Averages $1970-88$

Central government surplus/GDP

Consolidated public surplus/GDP

Revenue components as shares of GDP:

Total revenue including grants

Total revenue

Tax revenue

Nontax revenue

Current revenue

Social security contributions

Expenditure components as shares of GDP:

Government consumption [Barro-Wolf (1989)]

Government consumption excluding defense and education [Barro-Wolf (1989)] -0.32

General public services

Expenditures on social security

Government transfers [Barro-Wolf (1989)]

Other tax variables:

'Marginal' income tax rate from regression of income tax revenue on GDP $\quad-0.26$

Standard deviation of ratio of domestic taxes to consumption plus investment $\quad-0.39$

Standard deviation of ratio of international trade taxes to imports plus exports $\quad-0.18$

those distortion effects. The key piece of information used in constructing those three measures is the revenue collected by the government. Taxes that generate little revenue are implicitly assumed to create small distortions. In practice, however, there are highly distortionary taxes that generate little revenue (the corporate income tax in the U.S., whose revenue is currently $2 \%$ of GNP, is often thought to be one such example).

\subsection{Cross-section regressions}

Table 1 reports the simple correlations between fiscal variables and the growth rate that are statistically significant. Existing theoretical models make no predictions about the sign of unconditional correlations. However, we will later show that the government surplus, government consumption, and the 'marginal' tax rate on income (computed with a time-series regression) continue to be correlated with growth after we control for the effects of other variables.

Our point of departure for a multivariate analysis is a version of the Barro (1991) regression. We followed Levine and Renelt (1992) in using World Bank data instead of Summers and Heston (1991) data to construct per capita income growth rates. This procedure reduces the possibility of the negative coefficient on initial income, typically found in Barro (1991) type regressions, being an 
artifact of measurement error in income. Watson's (1992) finding that the least squares growth rate is more robust to differences in the serial correlation properties of the data than the geometric rate of growth led us to compute all growth rates by running a least squares regression of the logarithm of income on time.

Our basic regression, with $t$-statistics given in parentheses, is the following: ${ }^{5}$

$$
\begin{aligned}
& \text { GROWTH RATE OF PER CAPITA GDP } 1970-88 \\
&=0.003-0.004(P E R \text { CAPITA GDP 1960) } \\
&(0.51) \quad(-2.81) \\
&+\quad 0.023(\text { PRIMARY ENROLLMENT 1960) } \\
& \quad(3.15) \\
&+ 0.025 \text { (SECONDARY ENROLLMENT 1960) } \\
&(1.88) \\
&- 0.003 \text { (ASSASSINATIONS PER MILLION) } \\
&(-1.47) \\
&- 0.01(\text { REVOLUTIONS AND COUPS) } \\
&(-1.29) \\
&- 1.157 \text { (WAR CASUALTIES PER CAPITA). } \\
&(-1.67)
\end{aligned}
$$

The $R^{2}$ of this regression is 0.29 , while the number of observations employed is 105.

In extensions of the neoclassical growth model such as Mankiw, Romer, and Weil (1992) and in endogenous growth models such as Lucas (1988) the rate of growth is a function of two state variables: the initial level of physical capital and the initial level of human capital. In models such as those of Becker, Murphy, and Tamura (1990) and Azariadis and Drazen (1990) the initial level of human capital is also an important determinant of future growth. The two school enrollment variables are included as proxies for the initial level of human capital, while the initial level of income is included in lieu of the initial stock of physical capital. The motivation for the inclusion of measures of political turmoil is obvious. ${ }^{6}$ We will later report results that include M2/GDP in 1970 and the trade share in 1970. These variables were included to hold fixed the effects of other policies that

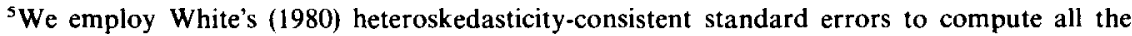
$t$-statistics reported in the paper.

${ }^{6}$ Data on war casualties is from Easterly, Kremer, Pritchett, and Summers (1993).
} 


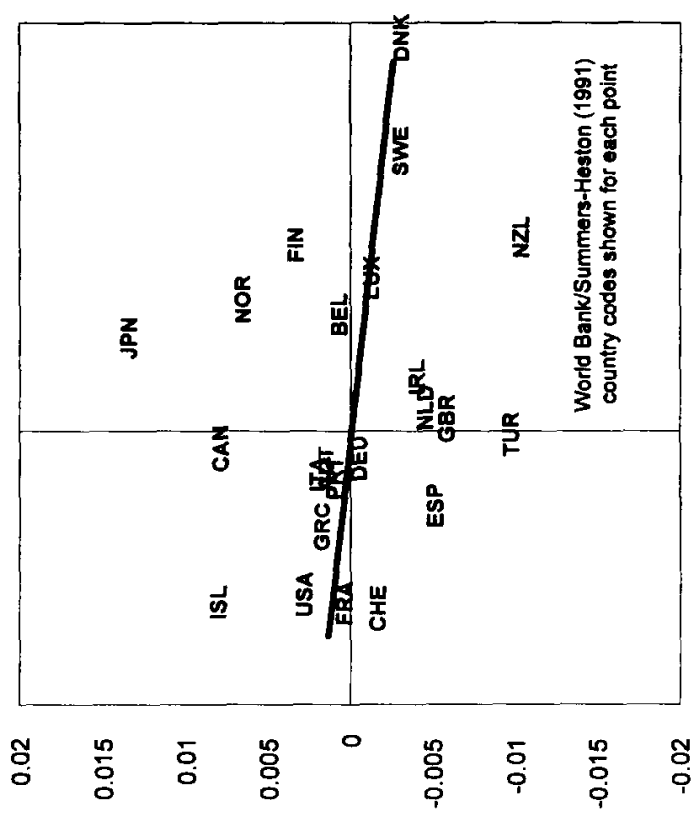

พ

?

(

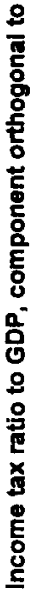

$\infty$

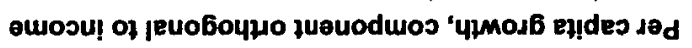

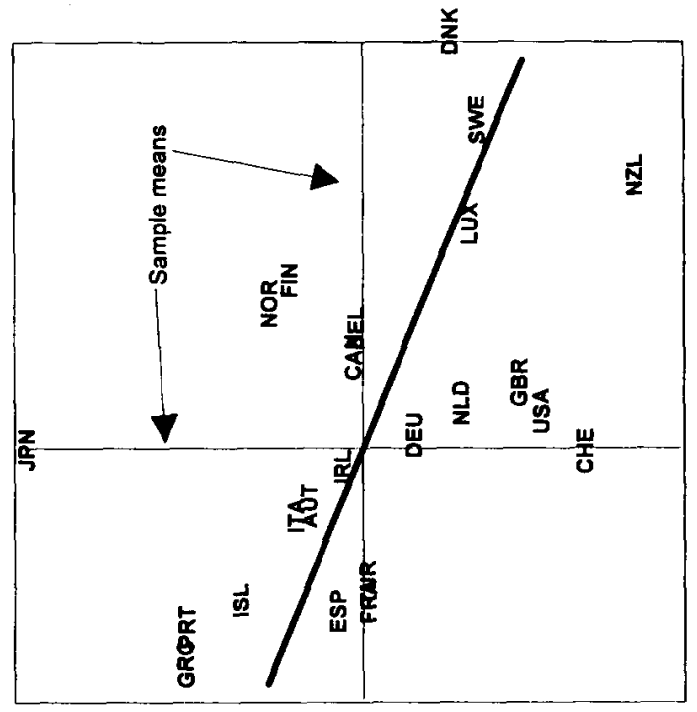

$\stackrel{\text { N }}{2}$

$\infty$
$\infty$
1
8
0

:

正 8

ஓ

ए छ

章

ڤั

咅

䓂

믈

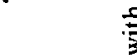

怘 造

요

兽

$\approx$ 哭

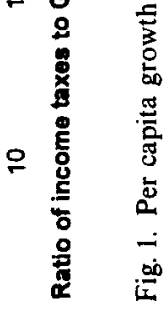

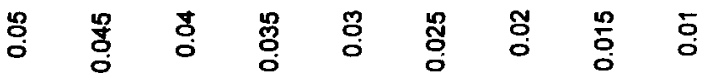

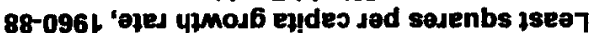


have been shown to be robustly correlated with growth and investment by Levine and Renelt (1992) and King and Levine (1993).

When we expand this regression by including our measures of fiscal policy one at a time, we find that these tend to be insignificant, often causing the coefficient on initial income to become statistically insignificant as well. There is a strong correlation between our fiscal variables and the log of per capita income, so it is difficult to disentangle the effects of fiscal variables from those of the initial level of income. This problem becomes more severe when we include more than one fiscal policy variable on the right-hand side.

Fig. 1 illustrates the importance the interaction between tax variables and the initial level of income. The top panel of this figure shows the impressive negative relation between the rate of growth and the ratio of tax revenues to GDP uncovered by Plosser (1993) for OECD countries. The bottom panel of this figure shows that this negative relation disappears completely once we control for the initial level of income.

Table 2 reports the significance of various tax rate variables and of the initial level of income in extended versions of the basic regression described above, in which we introduce one tax variable at a time. In these regressions the sign of the coefficients on income and on the tax variables (not reported in the table) is always negative. The significance of income is often weakened substantially

Table 2

Significance of tax rate variables and initial income in Barro regression, 1970-88 cross-section.

Tax rate

Significance level

Significance level of income of tax rate

Tax rates computed with time series regressions:

Koester-Kormendi (1989) 'marginal' tax rate

0.014

0.194

'Marginal' income tax rate from time series regression on GDP

0.015

0.047

'Marginal' tax rate from time series regression

of total revenue on GDP

0.013

Tax rates computed as ratios of tax revenue to tax base:

Taxes on income, profits, and capital gains/GDP

0.093

0.353

International trade taxes/Imports plus exports

0.158

0.243

Individual income taxes/Personal income

0.057

0.098

Sicat-Virmani statutory tax rates:

On first bracket

0.043

On $0.75 \times$ average family income

On $2 \times$ average family income

On $3 \times$ average family income

On highest bracket

0.045

0.074

0.432

0.101

0.386

0.075

0.958

Easterly-Rebelo (1993) marginal tax rate

0.077

0.587

0.687

Basic regression with no fiscal variables

0.006 
Table 3

Tax rates, growth, and private investment.

\begin{tabular}{|c|c|c|c|c|}
\hline \multirow{3}{*}{$\frac{\text { Independent variables }}{\text { Constant }}$} & \multicolumn{4}{|c|}{ Dependent variables } \\
\hline & \multicolumn{2}{|c|}{$\begin{array}{l}\text { Growth rate of per } \\
\text { capita GDP }\end{array}$} & \multicolumn{2}{|c|}{$\begin{array}{l}\text { Ratio of private } \\
\text { investment to GDP }\end{array}$} \\
\hline & $\begin{array}{c}0.010 \\
(1.109)\end{array}$ & $\begin{array}{l}0.0008 \\
(0.16)\end{array}$ & $\begin{array}{r}0.086 \\
(4.32)\end{array}$ & $\begin{array}{r}0.087 \\
(4.127)\end{array}$ \\
\hline GDP per capita, 1960 & $\begin{array}{l}-6.46 \mathrm{e}-03 \\
(-2.25)\end{array}$ & $\begin{array}{l}-2.89 \mathrm{e}-03 \\
(-1.93)\end{array}$ & $\begin{array}{l}8.42 \mathrm{e}-03 \\
(0.91)\end{array}$ & $\begin{array}{l}-5.8 \mathrm{e}-3 \\
(-0.79)\end{array}$ \\
\hline Primary enrollment, 1960 & $\begin{array}{l}0.0247 \\
(2.24)\end{array}$ & $\begin{array}{r}0.025 \\
(3.01)\end{array}$ & $\begin{array}{l}0.083 \\
(3.44)\end{array}$ & $\begin{array}{l}0.073 \\
(2.91)\end{array}$ \\
\hline Secondary enrollment, 1960 & $\begin{array}{l}0.0439 \\
(2.09)\end{array}$ & $\begin{array}{l}0.031 \\
(1.95)\end{array}$ & $\begin{array}{l}-0.051 \\
(-0.53)\end{array}$ & $\begin{array}{l}-0.022 \\
(-0.36)\end{array}$ \\
\hline Assassinations per million, $1970-85$ & $\begin{array}{l}-65.7 \\
(-1.69)\end{array}$ & $\begin{array}{l}-65.4 \\
(-2.03)\end{array}$ & $\begin{array}{l}482.6 \\
(1.55)\end{array}$ & $\begin{array}{l}-70.3 \\
(-1.07)\end{array}$ \\
\hline Revolutions and coups, $1970-85$ & $\begin{array}{l}-0.0054 \\
(-0.39)\end{array}$ & $\begin{array}{l}-0.009 \\
(-1.01)\end{array}$ & $\begin{array}{l}-0.038 \\
(-1.33)\end{array}$ & $\begin{array}{r}0.015 \\
(0.509)\end{array}$ \\
\hline War casualties per capita, $1970-88$ & $\begin{array}{l}-1.436 \\
(-2.225)\end{array}$ & $\begin{array}{c}3.28 \\
(1.33)\end{array}$ & $\begin{array}{l}5.88 \\
(0.993)\end{array}$ & $\begin{array}{l}-3.63 \\
(-4.77)\end{array}$ \\
\hline $\begin{array}{l}\text { 'Marginal' income tax rate with respect } \\
\text { to GDP }\end{array}$ & $\begin{array}{l}-0.064 \\
(-2.04)\end{array}$ & & & $\begin{array}{l}-0.193 \\
(-3.30)\end{array}$ \\
\hline $\begin{array}{l}\text { Ratio of individual income taxes to } \\
\text { personal income }\end{array}$ & & 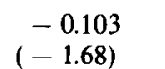 & & \\
\hline $\begin{array}{l}\text { Ratio of domestic taxes to consumption } \\
\text { plus investment }\end{array}$ & & & $\begin{array}{l}-0.737 \\
(-2.702)\end{array}$ & \\
\hline $\begin{array}{l}\text { Number of observations } \\
R^{2}\end{array}$ & $\begin{array}{l}53 \\
0.362\end{array}$ & $\begin{array}{c}74 \\
0.261\end{array}$ & $\begin{array}{l}57 \\
0.468\end{array}$ & $\begin{array}{l}43 \\
0.378\end{array}$ \\
\hline
\end{tabular}

when tax variables are included in the regression. Seven out of the thirteen tax measures included in this table render the initial level of income insignificant in the regression. The only tax rate variable that is significant at the $5 \%$ level is a 'marginal' income tax rate computed by using individual country time series to regress income tax revenue on GDP. This table shows that it is difficult to disentangle the 'convergence' effect discussed by Barro and Sala-i-Martin (1992) from the effects of fiscal policy. This problem remains when we include measures of other policies in the regression and/or when we include other fiscal variables.

Table 3 reports the complete set of regression coefficients for those regressions in which tax rate coefficients are significant both with the rate of growth and the ratio of private investment to GDP as dependent variables. The private investment variable was constructed as total investment from Summers and Heston (1991) minus our own measure of consolidated public investment, which we describe in more detail below. 
Table 4

Partial correlations between fiscal aggregates, growth, and private investment.

\begin{tabular}{|c|c|c|c|}
\hline Fiscal variables & $\begin{array}{l}\text { Basic } \\
\text { regression }\end{array}$ & $\begin{array}{c}\text { Basic } \\
\text { regression } \\
\text { with } \mathrm{M} 2 / \mathrm{GDP}\end{array}$ & $\begin{array}{c}\text { Basic } \\
\text { regression } \\
\text { with } \mathrm{M} 2 / \mathrm{GDP} \\
\text { and trade share }\end{array}$ \\
\hline \multicolumn{4}{|c|}{ Significant coefficients in growth regression } \\
\hline Central government surplus/GDP & $\begin{array}{l}0.142 \\
(3.13)\end{array}$ & $\begin{array}{c}0.133 \\
(2.41)\end{array}$ & $\begin{array}{l}0.129 \\
(2.22)\end{array}$ \\
\hline Nontax revenue/GDP & $\begin{array}{l}0.170 \\
(2.72)\end{array}$ & $\begin{array}{l}0.056 \\
(0.66)\end{array}$ & $\begin{array}{l}0.106 \\
(1.14)\end{array}$ \\
\hline Capital revenue/GDP & $\begin{array}{r}1.584 \\
(5.36)\end{array}$ & $\begin{array}{c}1.710 \\
(3.07)\end{array}$ & $\begin{array}{r}1.810 \\
(2.93)\end{array}$ \\
\hline $\begin{array}{l}\text { Real government consumption } \\
\text { net of education and defense } \\
\text { expenditure/Real GDP }\end{array}$ & $\begin{array}{l}-0.098 \\
(-2.68)\end{array}$ & $\begin{array}{l}-0.064 \\
(-1.35)\end{array}$ & $\begin{array}{l}-0.075 \\
(-1.56)\end{array}$ \\
\hline $\begin{array}{l}\text { 'Marginal' income tax rate from } \\
\text { time series regression on GDP }\end{array}$ & $\begin{array}{l}-0.064 \\
(-2.04)\end{array}$ & $\begin{array}{l}-0.069 \\
(-1.62)\end{array}$ & $\begin{array}{l}-0.051 \\
(-1.19)\end{array}$ \\
\hline $\begin{array}{l}\text { Standard deviation of ratio of } \\
\text { domestic taxes to } \\
\text { consumption plus investment }\end{array}$ & $\begin{array}{l}-0.674 \\
(-4.35)\end{array}$ & $\begin{array}{l}-0.670 \\
(-3.40)\end{array}$ & $\begin{array}{l}-0.646 \\
(-3.13)\end{array}$ \\
\hline $\begin{array}{l}\text { Sicat-Virmani statutory income tax } \\
\text { rates on } 3 \times \text { average family income }\end{array}$ & $\begin{array}{l}0.0001 \\
(0.55)\end{array}$ & $\begin{array}{l}-0.0005 \\
(-1.86)\end{array}$ & $\begin{array}{l}-0.0007 \\
(-2.13)\end{array}$ \\
\hline $\begin{array}{l}\text { Expenditure on general public } \\
\text { services/GDP }\end{array}$ & $\begin{array}{l}-0.236 \\
(-3.38)\end{array}$ & $\begin{array}{l}-0.150 \\
(-1.22)\end{array}$ & $\begin{array}{l}-0.240 \\
(-1.78)\end{array}$ \\
\hline
\end{tabular}

Significant coefficients in private investment regression

Central government surplus/GDP

$\begin{array}{ccc}0.694 & 0.781 & 0.814 \\ (2.75) & (2.27) & (2.50)\end{array}$

Ratio of real government consumption to real GDP

Real government consumption net of education and defense expenditure/Real GDP

Standard deviation of ratio of international trade taxes to imports plus exports

$\begin{array}{lll}-0.267 & -0.595 & -0.664\end{array}$

$(-1.42) \quad(-2.08) \quad(-1.85)$

$\begin{array}{lll}-0.551 & -0.962 & -0.948\end{array}$

$\begin{array}{lll}(-2.08) & (-2.66) & (-2.48)\end{array}$

Domestic taxes/GDP

$\begin{array}{llr}-1.380 & -1.244 & -1.740 \\ (-2.36) & (-1.65) & (-2.00)\end{array}$

Domestic taxes/Consumption plus investment

$-0.772$

$(-2.32)$

$-0.889$

$-0.820$

$-0.737$

$(-2.13)$

$(-2.09)$

$(-2.70)$

$-0.723$

$-0.602$

Standard deviation of ratio of

$-2.091$

$(-2.11)$

$(-1.86)$ domestic taxes to consumption

$(-1.75)$

$-3.880$

$-3.772$ plus investment

'Marginal' income tax with respect to GDP

$-0.193$

$(-2.71)$

$(-2.96)$

Sicat-Virmani statutory income tax rates on average family income

$(-3.30)$

$-0.225$

$-0.177$

$-0.002$

$(-2.43)$

$(-2.07)$

$(-1.34)$

$-0.002$

$-0.003$

$-0.748$

$(-1.17)$

$(-2.47)$

Expenditure on general public

$-1.642$

$-1.755$ services/GDP

$(-1.57)$

$(-2.50)$

$(-2.64)$ 
Table 4 reports the significant coefficients relating private investment, growth, and our measures of fiscal policy. In these regressions we used the same conditioning variables as before: the level of income in 1960, primary and secondary enrollment in 1960, the three measures of political instability (number of assassinations, revolts and coups, and war casualties), M2/GPD in 1970, and the trade share in 1970.

The central government surplus is one of the fiscal variables whose relation with growth is most robust. The positive association between government surplus and growth can be given at least three interpretations. The first is tax smoothing which implies that high deficits are associated with periods of low growth. The second is that high deficits may just be proxying for high public debt, which in turn may signal higher taxes and lower public capital in the future. ${ }^{7}$ The third interpretation, proposed by Fischer (1993), is that large deficits are simply a symptom of general macroeconomic instability which is detrimental to economic growth.

The standard deviation of the ratio domestic taxes to consumption plus investment shows also a robust association with growth and private investment. This variable may be proxying for general instability in the economy as well as for variability associated with the tax system.

\subsection{The effects of public investment}

The concepts of public investment used in GFS are highly problematic for LDCs. GFS achieves 'comparability' of these concepts across countries by reporting only the investment of the Central Government. Since activities that are associated with the central government in some countries are carried out in other countries by public enterprises, part of the cross-sectional variation in GFS public investment may reflect arbitrary differences in institutional arrangements. ${ }^{8}$

To correct for this potential bias we have constructed new measures of public investment through a large scale data collection exercise on aggregate and sectoral consolidated public investment. Our consolidated measure probably

\footnotetext{
${ }^{7}$ Unfortunately, the unavailability of the data on public debt in LDCs prevents us from trying to separate the effects of the deficit from those of the debt.

${ }^{8}$ The measure of government surpluses reported in GFS suffers from a similar problem as the GFS public investment data: it refers only to the central government rather than the consolidated public sector. However, the distortion in the GFS of the deficit measure is not as serious as that of the public investment measure, since central government deficits usually include transfers to the rest of the public sector to cover deficits in local governments and public enterprises. We report results with both the central government deficit and the consolidated public surplus from Easterly, Rodriguez, and Schmidt-Hebbel (1993).
}

Note to table 4 .

$t$-statistics are given in parentheses. Basic regression includes the level of income in 1960, primary and secondary enrollment in 1960, assassinations, revolutions and coups, and war casualties. 
overstates the amount of public investment by including investment by public firms that have activities and goals similar to those of the private sector. The error introduced by this fact is probably small compared to the bias introduced in the GFS public investment series by the arbitrary exclusion of various types of infrastructure investment carried out by public firms in LDCs.

Our data source was the large collection of World Bank reports on public investment in individual countries since 1960. An earlier exercise [Pfeffermann and Madarassy (1991)] collected consolidated public investment from a selection of these reports. We expanded this list to more countries and more years: our data set comprises observations on public investment for 36 countries in the $60 \mathrm{~s}, 108$ countries in the 70s, and 119 countries in the 80s. More importantly, we collected data on public investments by sector and by levels of government from these reports, the first time we are aware that this has been done comprehensively. We have supplemented the data we collected for aggregate public investment with other sources, including Pfeffermann and Madarassy (1991), the World Bank (1991), and the United Nations national accounts. Our public investment series can be found in the appendix.

The correlation between Central Government Investment and Consolidated Public Sector Investment in the 1980s (the decade for which our data set is more complete) is 0.63 , while the median difference between the two rates of investment is 7 percentage points of GDP.

We constructed decade-average public investment ratios by sector from the available data in each decade and entered them into pooled regressions of decade-average per capita growth. We performed regressions using decade averages because of the sparseness of the data. The information on public investment is often available for too few years to allow us to compute meaningful averages over periods that are longer than a decade.

We used a similar set of conditioning variables in these regressions as in section 3.1. This set of variables comprises the initial level of income, and decade averages of: primary and secondary enrollment, measures of political instability (assassinations, revolts and coups, and war casualties), and the ratio of government consumption to GDP. ${ }^{9}$ We extend this regression to include one public investment variable at a time. We report three sets of results in table 5: the basic regression, in which the conditioning variables are the Barro regressors, a version of this regression in which we include the ratio of M2 to GDP as explanatory variable, and another version of the regression in which both the value of M2/GDP and of the trade share in 1970 are included in the right-hand side. In table 6 we repeat the same analysis with private investment as the

\footnotetext{
${ }^{9}$ Government consumption serves as a proxy for taxes collected and then dissipated unproductively as in Barro (1991). When we used our other tax measures instead of government consumption, the number of observations was in general greatly reduced and most of the regression coefficients became statistically insignificant.
} 
Table 5

Regressions of per capita growth on public investment and conditioning variables (pooled regressions with decade averages).

\begin{tabular}{lccc}
\hline Ratios to GDP & Basic regression & $\begin{array}{c}\text { Basic regression } \\
\text { with M2/GDP }\end{array}$ & $\begin{array}{c}\text { Basic regression } \\
\text { with M2/GDP } \\
\text { and trade share }\end{array}$ \\
\hline Total consolidated public investment & 0.040 & -0.00007 & -0.004 \\
Sectoral public investment: & $(1.02)$ & $(-0.002)$ & $(-0.089)$ \\
Agriculture & -0.231 & -0.34 & -0.304 \\
Education & $(-1.13)$ & $(-1.50)$ & $(-1.36)$ \\
Health & 1.490 & 1.10 & 1.18 \\
Housing and urban infrastructure & $(2.26)$ & $(1.54)$ & $(1.60)$ \\
Transport and communication & 0.011 & -0.40 & -0.37 \\
& $(0.02)$ & $(-0.54)$ & $(-0.49)$ \\
Industry and mining & 1.49 & 0.88 & 0.91 \\
& $(2.82)$ & $(1.46)$ & $(1.48)$ \\
Public investment by level of government: & 0.661 & 0.588 & 0.626 \\
General government & $(2.48)$ & $(2.53)$ & $(2.48)$ \\
Public enterprises & 0.218 & 0.089 & 0.082 \\
& $(1.39)$ & $(0.589)$ & $(0.53)$ \\
\hline
\end{tabular}

dependent variable. The financial variable is often (but not always) significant in both the private investment and the growth equation. Trade is sometimes significant (especially in the investment regression), but sometimes takes the wrong (negative) sign in the growth regression.

The main results suggested by these regressions are:

(a) Transport and communication investment seem to be consistently positively correlated with growth with a very high coefficient (between 0.59 and 0.66 ). This type of investment is uncorrelated with private investment suggesting, surprisingly, that it raises growth by increasing the social return to private investment but not by raising private investment itself. Transport and communication investment is still significant in the growth regression when we control for private investment.

(b) Total public investment, as well as public enterprise investment, is consistently negatively correlated with private investment. This result can, 
Table 6

Regressions of private investment on public investment and conditioning variables (pooled regressions with decade averages).

\begin{tabular}{lccc}
\hline Ratios to GDP & Basic regression & $\begin{array}{c}\text { Basic regression } \\
\text { with M2/GDP }\end{array}$ & $\begin{array}{c}\text { Basic regression } \\
\text { with M2/GDP } \\
\text { and trade share }\end{array}$ \\
\hline Total consolidated public investment & -0.194 & -0.223 & -0.241 \\
Sectoral public investment: & $(-2.08)$ & $(-2.19)$ & $(-2.57)$ \\
Agriculture & -0.943 & -0.66 & -0.74 \\
Education & $(-2.64)$ & $(-1.98)$ & $(-2.24)$ \\
Health & 1.987 & 2.28 & 1.96 \\
Housing and urban infrastructure & $(1.29)$ & $(1.56)$ & $(1.40)$ \\
Transport and communication & 0.027 & 2.56 & 2.29 \\
& $(0.02)$ & $(2.31)$ & $(1.95)$ \\
Industry and mining & 2.108 & 1.26 & 1.01 \\
Public investment by level of government: & $(1.65)$ & $(1.00)$ & $(0.85)$ \\
General government & 0.001 & 0.053 & -0.17 \\
Public enterprises & $(0.00)$ & $(0.13)$ & $(-0.43)$ \\
& -0.351 & -0.449 & -0.359 \\
\hline
\end{tabular}

however, be an artifact introduced by the fact that we constructed our private investment series by subtracting our public investment measure from total investment. Total public enterprise investment seems to have no effect on growth.

(c) General government investment is consistently positively correlated with both growth and private investment, with a coefficient of about 0.4 on growth and near 1 on private investment.

(d) Agriculture investment is consistently negatively related to private investment with a coefficient between -0.64 and -0.94 .

An important qualification of our results is that we cannot exclude the possibility that the association between public investment and growth is due to reverse causation: public investment may simply be higher in periods of fast expansion. 
One piece of indirect evidence against reverse causation is that only transport and communication investment and general government investment are robustly correlated with growth (the association between education and housing investment and growth is not robust). If the direction of causation were from growth to public investment, we would expect all types of public investment to be associated with growth.

In order to investigate whether reverse causation is responsible for our results, we instrument for the public investment variables. ${ }^{10}$ Fortunately, we have a natural set of instruments to use: as we will see in the next section, public investment and other fiscal variables depend on structural country characteristics like initial income, population size, and share of agriculture in GDP. Initial income is already in our basic growth regression, but the latter two variables are plausibly excluded from the growth regression. We also use continent dummies for Africa and Latin America because they are obviously exogenous and may be able to capture region-specific aspects of public investment.

The results on agriculture and public enterprise investment crowding out private investment do not remain significant in the instrumental variables regressions.

The effect of transport and communications on growth is robustly significant with instrumental variables, but the size of the coefficients is disturbingly high: we obtain a coefficient of 2 for transport and communication investment and a coefficient of 0.7 for general government investment. This seems to be a common puzzling feature of aggregate empirical work on infrastructure: Aschauer (1989) and Canning and Fay (1993) also report extremely high coefficients on infrastructure measures in growth regressions. ${ }^{11}$ A study by Bandyopadhyay and Devarajan (1993) lends some credence to the idea that public investment in transport and communication has high returns. These authors report that $e x$ post rates of return to World Bank projects in transport and communication are much higher than those in other sectors, even without considering indirect benefits.

\section{Is fiscal policy endogenous?}

There are two branches of theoretical literature that suggest the presence of strong endogeneity elements in the choice of fiscal policy, implying that the regressions that we reported in section 3 are contaminated by simultaneous equations bias. The first of these branches studies the optimal fiscal policy,

\footnotetext{
${ }^{10}$ We also ran the same regressions lagging the public investment variables one decade. This reduced dramatically the dimension of our sample, rendering almost all variables (including noninvestment variables) insignificant.

${ }^{11}$ These results contrast, however, with the findings of Holtz-Eakin (1992) who finds no impact of public capital on productivity growth after controlling for fixed effects across US states.
} 
usually under the assumption that the government seeks to maximize the welfare of the representative agent [see, e.g., Chamley (1986), Lucas (1990), and Jones, Manuelli, and Rossi (1993)]. Barro (1990) discusses the implications of fiscal policy being chosen optimally in the context of a specific model. In his model there is an inverted U-shape relation between the share of government expenditures in GDP and the rate of growth whenever the rate of income tax is chosen randomly. In contrast, if governments choose the optimal income tax rate, the relation between the share of government and the rate of growth can be significantly weakened.

The second branch of research that makes policy endogenous treats it as the outcome of a political process [see, e.g., Persson and Tabellini (1991), Cohen and Michel (1991), and Alesina and Rodrick (1991)]. This 'political economy' approach points to very few exogenous factors that can be used in the empirical analysis but has an implication that we examine below: democracies and nondemocracies should, in general, implement different policies. We also discuss the relation between policy variables and inequality, since this relation is at the core of many political economy models.

We have seen in section 3 that there is collinearity between certain elements of fiscal policy and initial income. Below we explore in more detail this and other possible determinants of fiscal policy.

\subsection{Cross-section evidence 197088}

Table 7 displays the correlations between fiscal variables and the logarithm of real per capita GDP in 1970 that are statistically significant. This table shows that developed countries tend to rely more on income and consumption taxes and less on international trade taxes. These patterns of association between the level of development and the character of the fiscal system are similar to those identified by Tanzi $(1987,1992)$ and discussed in Burgess and Stern (1993). In addition, the cross-section data suggests that health and social security expenditures increase with the level of income, while most other types of government expenditures are negatively associated with the level of development.

To investigate the presence of scale effects we regressed our fiscal variables on the values in 1970 of the logarithm population, the logarithm of real per capita GDP, the trade share, and the share of agriculture in GDP [the latter variable was found by Tanzi (1992) to be highly correlated with the fiscal structure]. We found that the ratio of social security contributions to total revenue is positively related to population, while the revenue share of taxes on international trade is negatively related to population. On the expenditure side, we also found strong scale effects: the share of public spending on capital formation, transport and communication, agriculture, and general public services falls with increased 
Table 7

Significant correlations of fiscal structure variables with the log of per capita income in 1970.

Averages, 1970-88

Aggregate variables:

$\begin{array}{lr}\text { Consolidated public sector surplus/GDP } & 0.49\end{array}$

Total revenue/GDP $\quad 0.55$

Grants/GDP $\quad-0.27$

Total expenditure and lending minus repayments/GDP $\quad 0.35$

$\begin{array}{lr}\text { Revenue components as share of total revenue (excluding grants): } & 0.21 \\ \text { Tax revenue } & -0.17\end{array}$

$\begin{array}{lr}\text { Nontax revenue } & -0.17\end{array}$

Taxes on income, profits, and capital gains $\quad 0.35$

$\begin{array}{lr}\text { Social security contribution } & 0.58\end{array}$

Taxes on international trade and transactions $\quad-0.75$

$\begin{array}{ll}\text { Payroll taxes } & 0.31\end{array}$

$\begin{array}{ll}\text { Expenditure components as share of total expenditure: } & -0.59 \\ \text { General public services } & \end{array}$

\begin{tabular}{ll} 
Education & -0.41 \\
\hline
\end{tabular}

Health $\quad 0.36$

$\begin{array}{lr}\text { Social security and welfare } & 0.78\end{array}$

Recreation, culture, and religion $\quad-0.28$

Agriculture, forestry, fishing, and hunting $\quad-0.54$

Fuel and energy -0.32

Transportation and communication $\quad-0.32$

Sicat-Virmani statutory tax rates:

On $0.75 \times$ average family income $\quad 0.46$

On average family income $\quad 0.47$

On $2 \times$ average family income $\quad 0.46$

On $3 \times$ average family income $\quad 0.44$

Other variables:

Ratio of individual income taxes to personal income $\quad 0.59$

$\begin{array}{ll}\text { Ratio of income taxes to GDP } & 0.51\end{array}$

Ratio of domestic taxes to consumption plus investment $\quad 0.48$

Ratio of trade taxes to exports plus imports -0.77

Standard deviation of ratio of trade taxes to exports plus imports $\quad 0.50$

'Marginal' tax rate [Koester-Kormendi (1989)]

'Marginal' tax rate from regression of tax revenue on GDP $\quad 0.39$

population size. In contrast, the share of defense is positively associated with population size.

These scale effects associated with government expenditures are likely to be related to nonconvexities in either the benefits or the costs of publicly provided goods and services. If a government service has the nonrival consumption property of a pure public good - defense is the classic example - then there is more incentive to provide it in a large scale economy. On the other hand, if there are high setup costs but low marginal costs to providing a particular public service, then the amount of spending per capita for a given per capita level of that service would fall with increased scale. 
We also regressed our measure of consolidated public investment on the logarithms of initial income and of population and on the share of agriculture (the trade share was excluded from the set of regressors because it seems less relevant for public investment and was usually insignificant when we included it in the regression). We found that total public investment falls with per capita income. Investment in public enterprises, in particular, is inversely related to income. We also found scale effects: countries with higher population have lower transport and communication investment. ${ }^{13}$

We investigated the political economy literature implication that fiscal policy should be different across democracies and nondemocracies. For this purpose we adopted the classification of countries into political regimes of Alesina and Rodrick (1991) and complemented it with the classification provided by Cukierman and Webb (1993). ${ }^{12}$ The fiscal policy variables that are significantly different between democracies and nondemocracies are essentially the same reported in table 7 as being significantly correlated with per capita income. This is due to the high correlation between the democracy dummy and the level of income in $1970(0.68)$. The vast majority of the democracies in our sample are rich countries: there are only three democracies with income below the crosssection median in 1970.

We were surprised to find that the character of the political system does not seem to matter in terms of fiscal policy once we control for income. We can only find one fiscal variable that is statistically different between democracies and nondemocracies after controlling for income: aid revenue (which, presumably, says more about the behavior of donors than recipients).

Since the distribution of income is a central element in political economy theories we examined the relation between fiscal policy variables and the degree of inequality in income distribution. We searched for the fiscal variables that were significantly correlated at the 5\% level (controlling for income) with at least three of the following measures of inequality: the share of the upper decile in income, the ratio of the richest quintile to the poorest $40 \%$, the share of the middle quintile, the Gini coefficient, and the Theil index. These inequality measures, compiled in Clarke (1992), were all computed with data prior to 1970 so that our correlations may be interpreted as the effect of inequality on fiscal policy. We found that countries with greater initial inequality prior to 1970 implement higher levels of public expenditure in education as a fraction of GDP in the period from 1970 to 1988.

\footnotetext{
${ }^{12}$ Cukierman and Webb (1993) provide a yearly classification of the political regimes for the countries in their sample. We classified a country as a democracy whenever, during the time period 1970-1988, it was a democracy more than $50 \%$ of the time; otherwise it is a nondemocracy.

${ }^{13}$ These results suggest that we should go back to the regressions in section 3 and use variables such as per capita income in 1960, population, the share of agriculture in GDP, the trade share, etc. to instrument for fiscal policy. We reported already in section 3.3 the instrumental variable results that we obtained in the case of public investment. When we tried to use the same instruments with the GFS variables we were unsuccessful: all the explanatory variables in the regression became insignificant, indicating that the instruments do not seem adequate.
} 


\subsection{Long-run evidence: $1870-1988$}

In order to investigate further the relation between fiscal policy, the level of development, and the scale of the economy, we constructed a panel that comprises annual data for the period from 1870 to 1988 and includes a total of 28 countries. ${ }^{14}$ This data was spliced together from various sources: Mitchell (1975, 1982, 1983), Maddison (1982), and Liesner (1989). To obtain a long-term series for real per capita GDP we used the Summers and Heston (1991) data for the period 1950-1988 and extended it backwards in time using the growth rate of real per capita GDP implied by our historical sources.

We divided income and the various fiscal variables in different classes and plotted the median of income against the median of the various fiscal variables for each class (the dashed lines around the median represent $95 \%$ confidence bands). These classes were constructed so as to have an identical number of observations.

We found three interesting (but not surprising) patterns in the evolution of fiscal variables. Fig. 2 shows the remarkable increase in the share of government revenue in national income that has occurred between 1870 and 1988. This increase in the importance of government in the economy has been explored in the large literature on 'Wagner's Law' [see, e.g., Ram (1987)].

Fig. 3 shows that the importance of custom taxes as a source of government revenue declines sharply with the level of income. This decline is particularly striking in the United States, where the importance of custom taxes in revenue drops from about $100 \%$ at the end of the 18 th century to approximately zero in 1988. ${ }^{15}$ Fig. 4 documents that the importance of the income tax as a source of government revenue rises with income.

Figs. 5 and 6 were constructed by classifying population size and income classified in three classes each and depicting the median share of income and custom tax revenue in overall revenue for the nine resulting classes. These figures show a striking association between population size and the importance of taxes on income and on international trade similar to the one suggested by our cross-section data: countries with higher population tend to resort less to trade taxes and more to income taxes.

Table 8 shows the results of a pooled time-series cross-section regressions in which we try to relate the evolution of the shares of income tax revenue and custom tax revenue in total revenue and the share of government revenue in

\footnotetext{
${ }^{14}$ The countries in our sample are: Argentina, Australia, Austria, Belgium, Brazil, Canada, Chile, Colombia, Denmark, Finland, France, Germany, Greece, Italy, Japan, Mexico, Netherlands, New Zealand, Norway, Peru, Portugal, Spain, Sweden, Switzerland, United Kingdom, Uruguay, USA, and Venezuela.

${ }^{15}$ Our data for the US includes only taxation at the Federal level. The taxation of business activity in general and of banking, in particular, was an important source of revenue in some US states during the 19th century [see Wallis, Sylla, and Legler (1993)].
} 


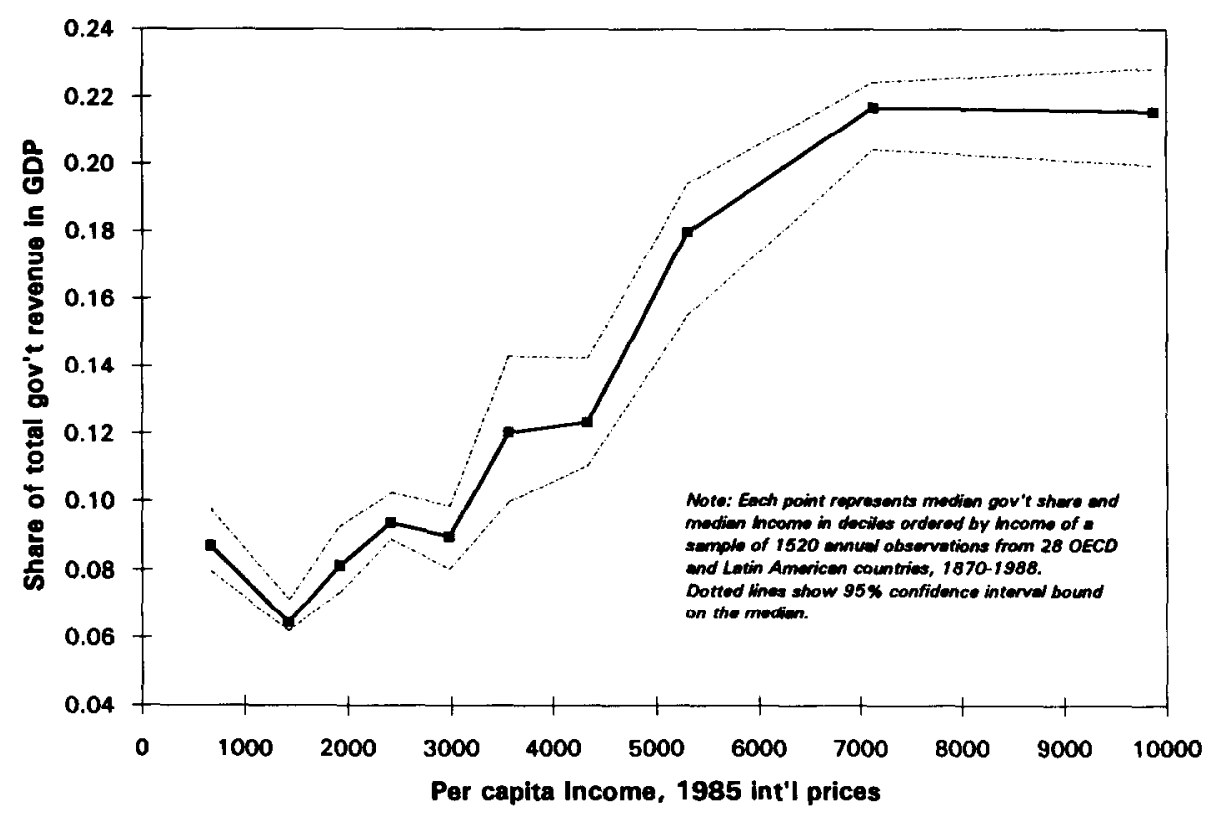

Fig. 2. Wagner's Law, income and size of government, 1870-88.

GDP to a set of explanatory variables. These variables, measured at the annual frequency, include the logarithm of real per capita GDP, the logarithm of population, dummies for the two World Wars, and a time trend.

The coefficient on the logarithm of real per capita GDP has the expected sign: positive for the income tax and government revenue ratios and negative for the share of custom taxes. There is a significant time trend that points to a gradual increase over time in the importance of government revenue in GNP and of income tax revenue in overall revenue. This trend also suggests a gradual decline in the importance of custom taxes.

Table 8 confirms the result that was already suggested by figs. 5 and 6 and by our cross-section data: the logarithm of population is a significant explanatory variable. Population is positively related to the importance of income taxes and of government revenue, while it is negatively related to the custom revenue share. This effect of population does not disappear when we introduce the share of trade in GNP in the regression, thus suggesting the presence of a scale effect associated with population on the character of the tax system. The trade share is negatively associated with customs revenue, since international trade is important in countries with low customs taxes.

The effects of the level of income and of the level of population on the character of the fiscal system are surely related to the administrative and 


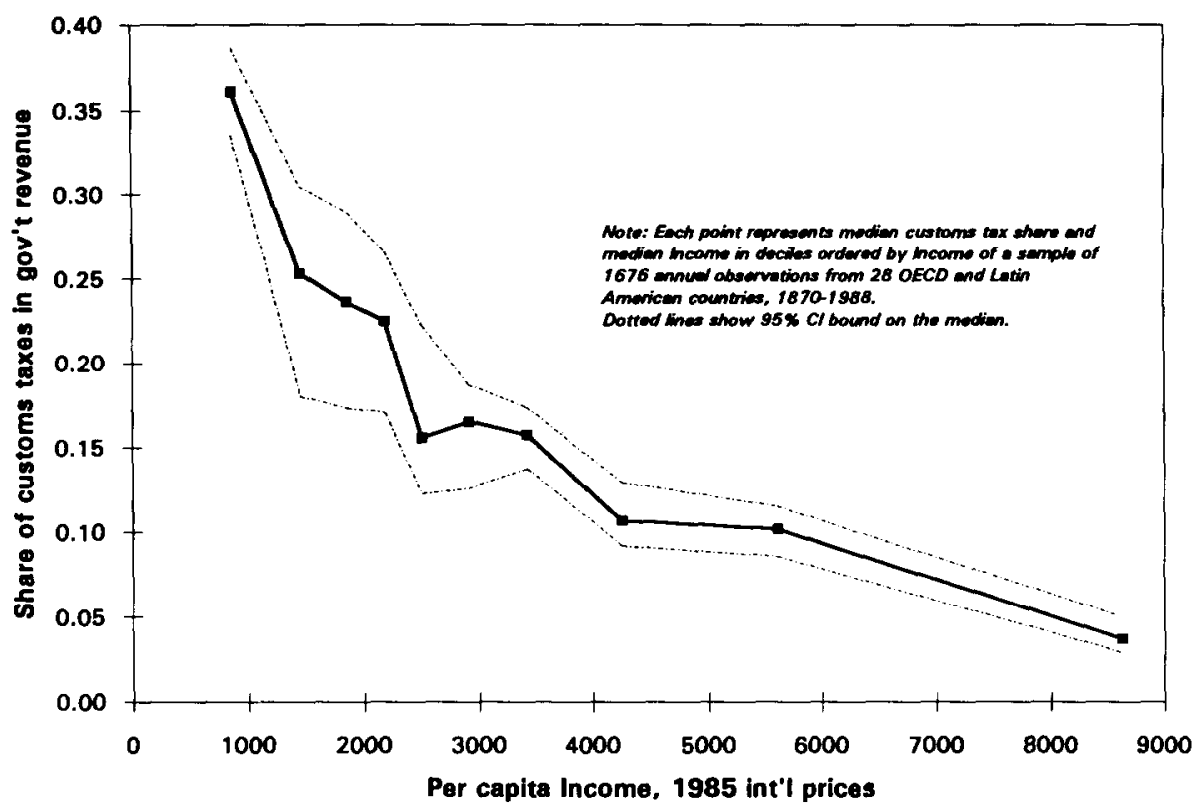

Fig. 3. Per capita income and share of custom taxes, 1870-88.

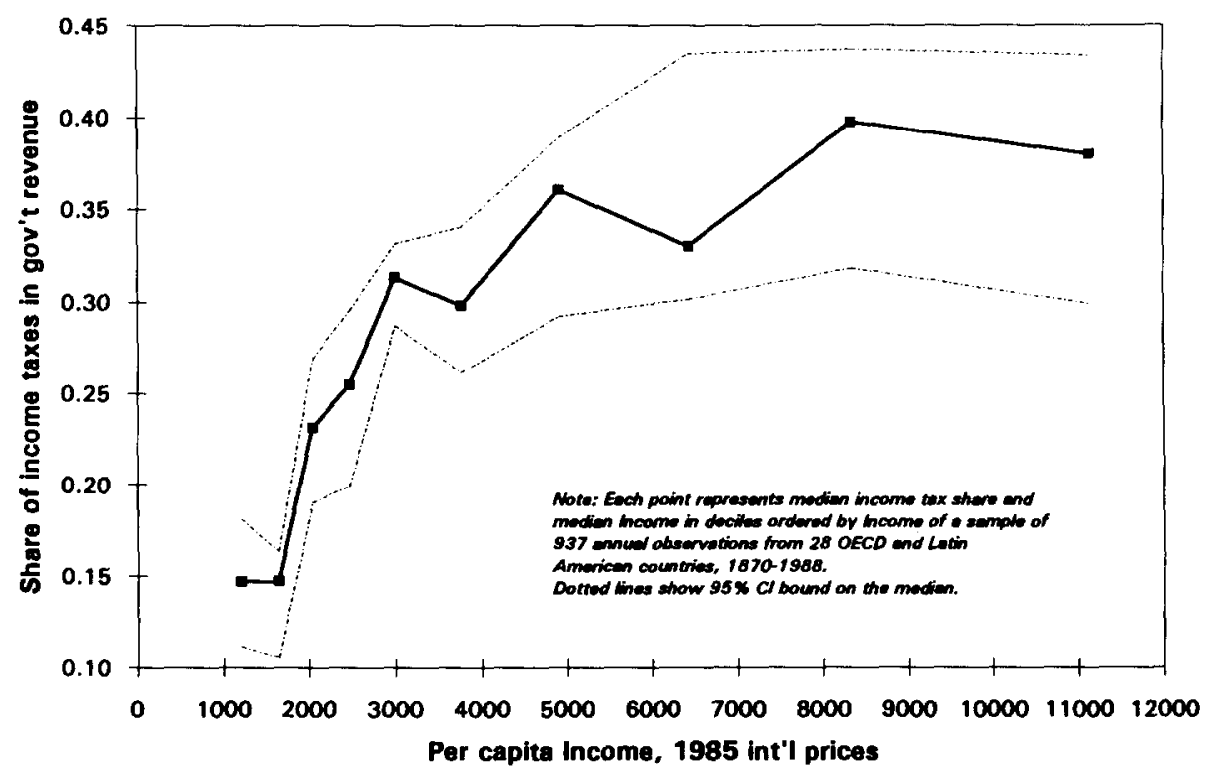

Fig. 4. Per capita income and share of income taxes, 1870-88. 


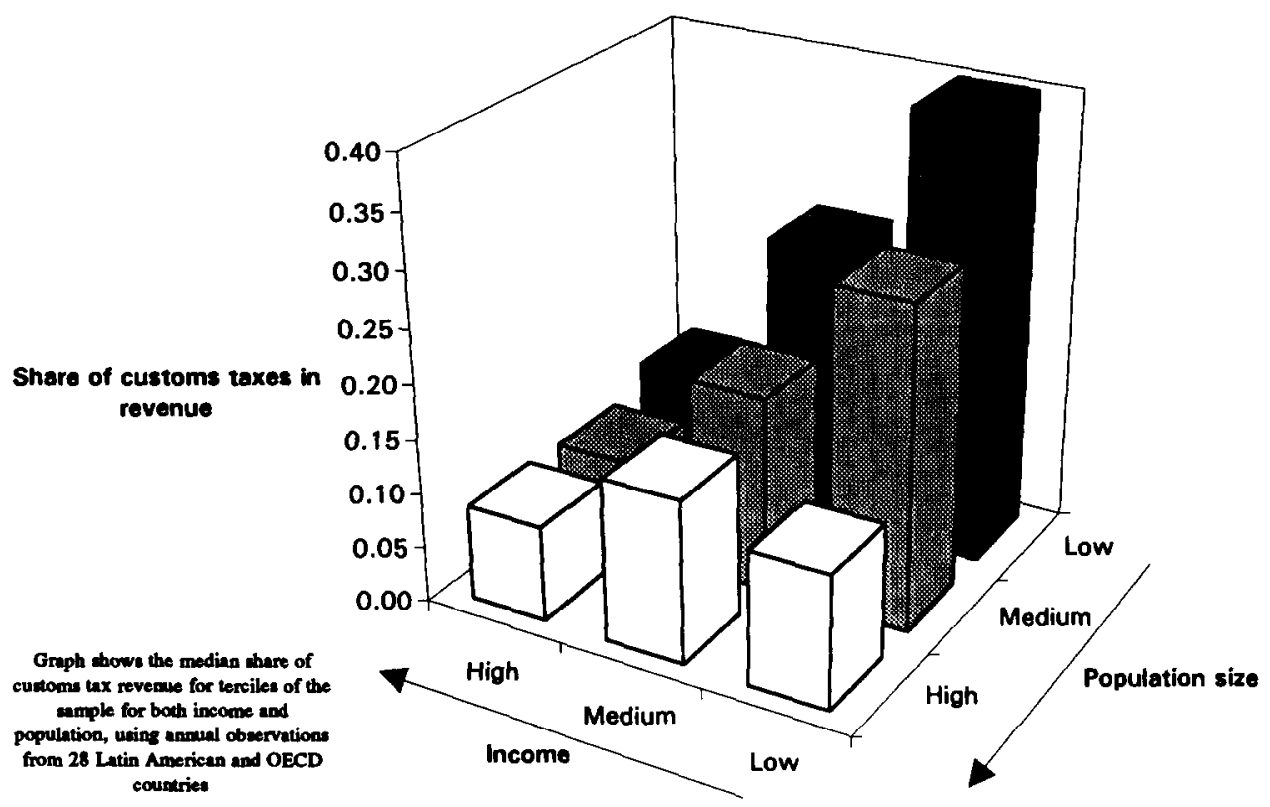

Fig. 5. Income, population size, and share of custom taxes in revenue, 1870-88.

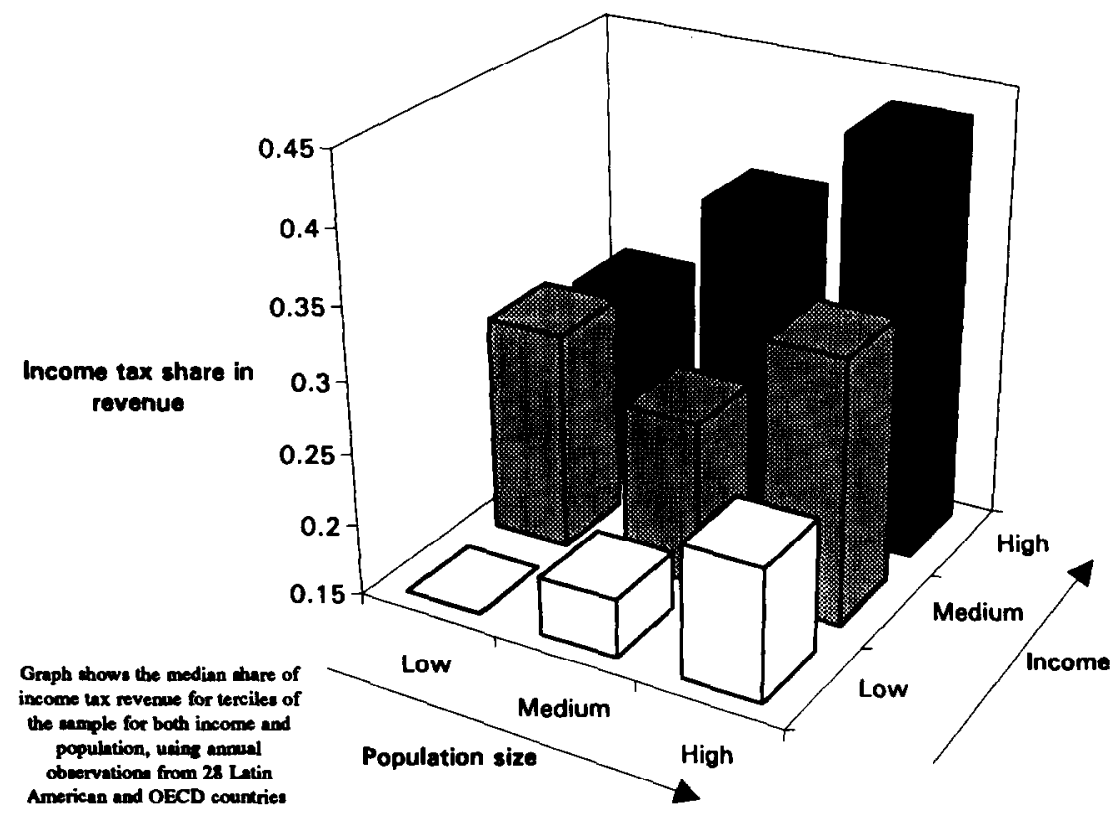

Fig. 6. Income, population size, and share of income taxes in revenue, 1870-88. 


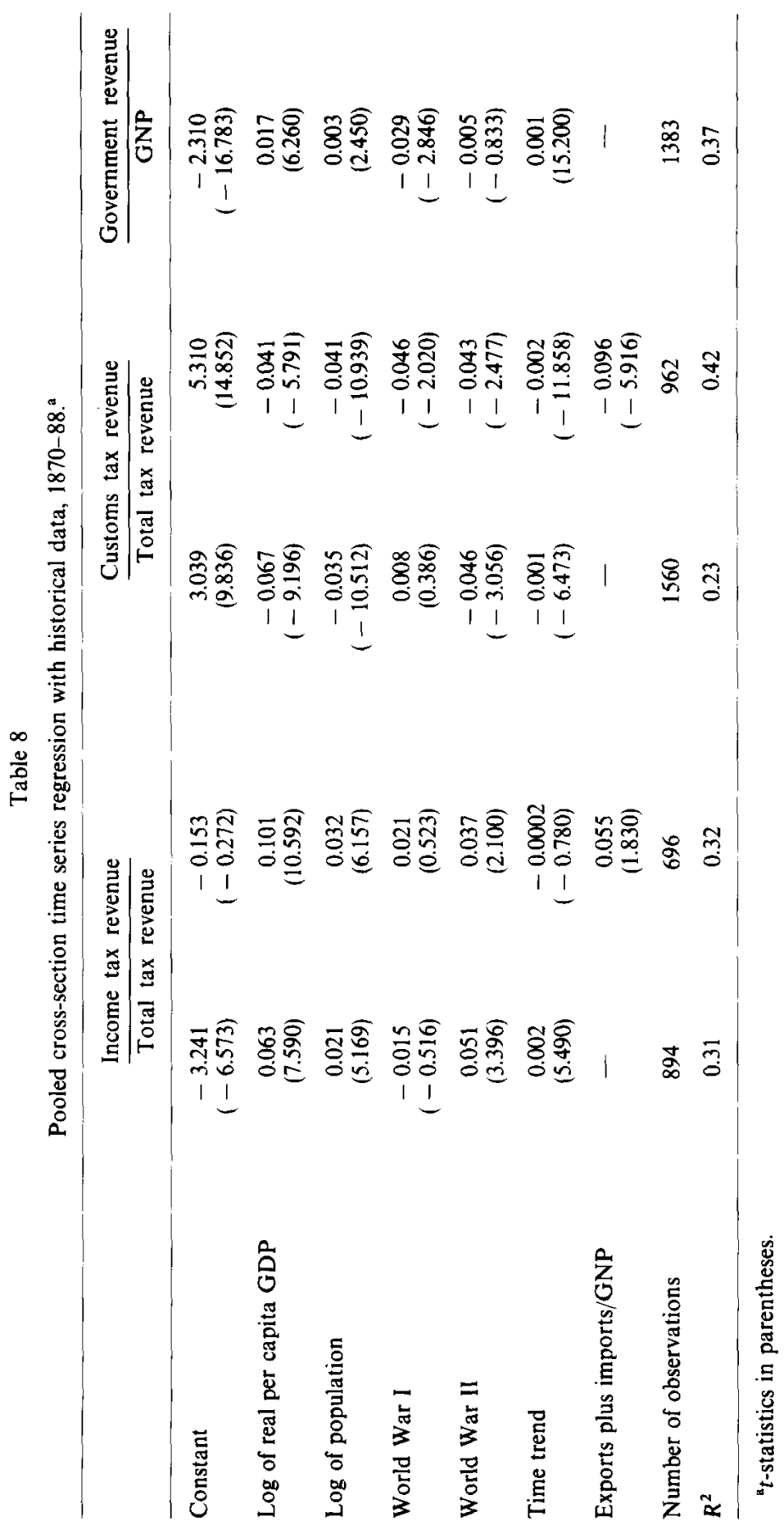


compliance costs of taxation. These costs are not small: in a study for Canada, Vaillancourt (1989) estimated that the total private and government operating costs associated with the income tax and the social security payments represent $7.1 \%$ of the revenue collected. In a similar study for the UK in the period 1986-87, Sandford, Godwin, and Hardwick (1989) estimated that these costs represent $4.93 \%$ of revenue.

It is plausible that custom taxes require little or no overhead expenditures, but are costly to administer per unit of tax collected. Income taxes imply high overhead costs for establishing income reporting, surveillance, and withholding systems, but once such overhead costs are paid, the marginal cost of an additional unit of tax collected is low. Under these circumstances, a government in a small scale economy (low population size, low income, or both) would prefer to use custom taxes, while a government in a large economy would find it worthwhile to bear the fixed costs of collecting income taxes.

\section{Further directions}

The empirical regularities summarized in this paper suggest a number of lines of further inquiry. One is the influence of economic scale on the choice of fiscal instruments. The literature has often noted the dependence of fiscal structure on income, but has not interpreted this relation as having anything to do with the scale of the economy. Our results on population, income, and fiscal structure suggest that scale matters. In order to be consistent with these scale effects, theoretical analyses of the choice of fiscal systems will have to take into account the cost of administering different tax systems, as well as the lumpiness of some types of expenditures. Distributional objectives are an additional consideration for the design of fiscal system: we found evidence that inequality affects education spending.

The evidence that tax rates matter for growth is disturbingly fragile. This empirical fragility contrasts sharply with the robustness of the theoretical predictions: most growth models predict that income and investment taxes are detrimental to growth. Our results on the dependence of both growth and tax policy on initial income help explain why it is difficult to isolate the effects of tax policy on growth. One avenue for further empirical research is to search for natural experiments in which there are large changes in tax policy, where the covariation with income does not constitute a problem.

Our results on public investment in transport and communication seem to lend support from developing country experiences to Aschauer's (1989) contention that public spending on infrastructure has supernormal returns. We have some suggestive evidence that causality runs from infrastructure to growth, but further work is necessary to address both causality questions and the surprising high magnitude of coefficients on public infrastructure spending. Much more data collection on infrastructure is needed, given the paucity of data on comprehensive infrastructure spending in most countries; our public investment data set is a beginning in this regard. 


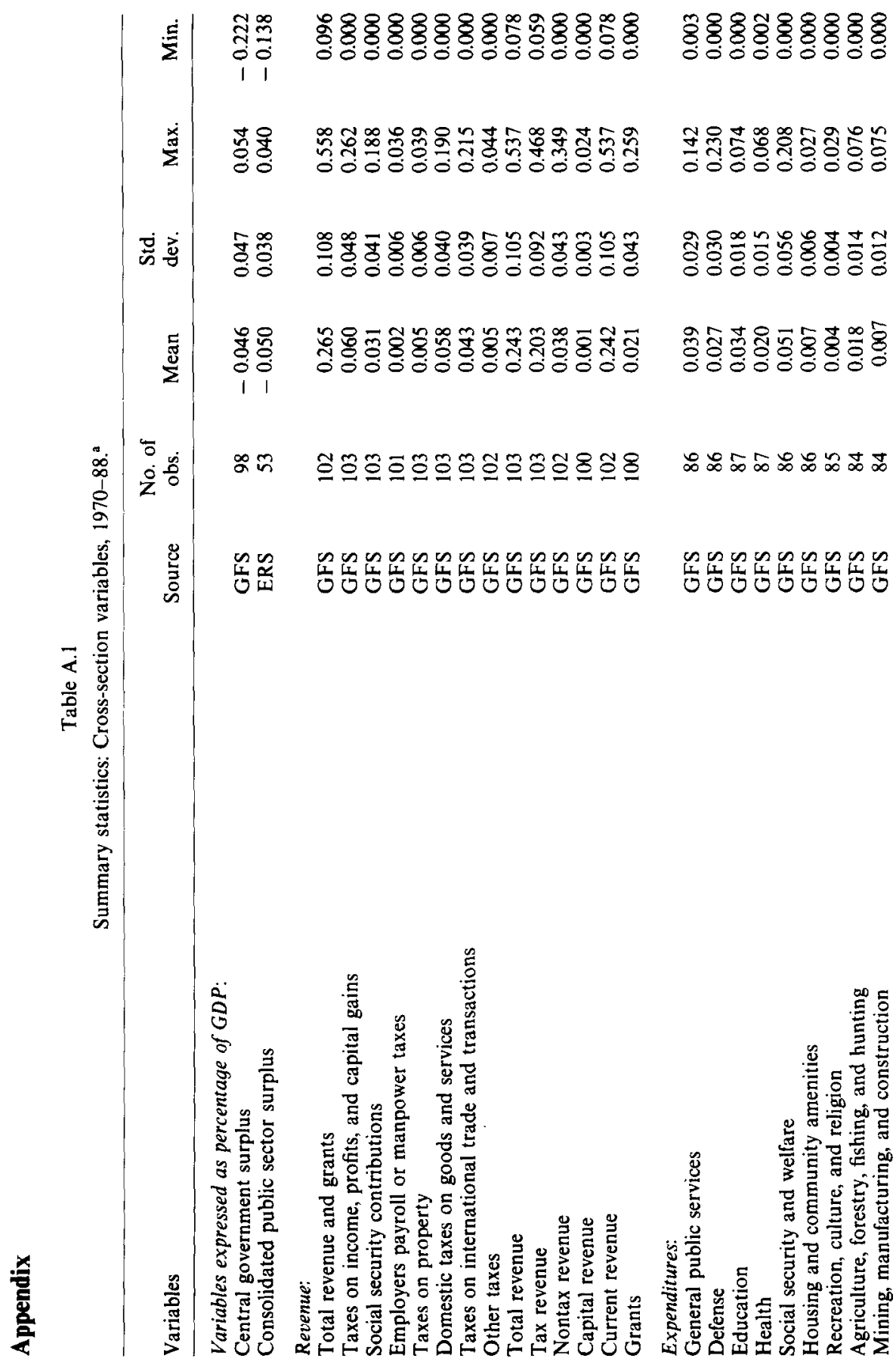




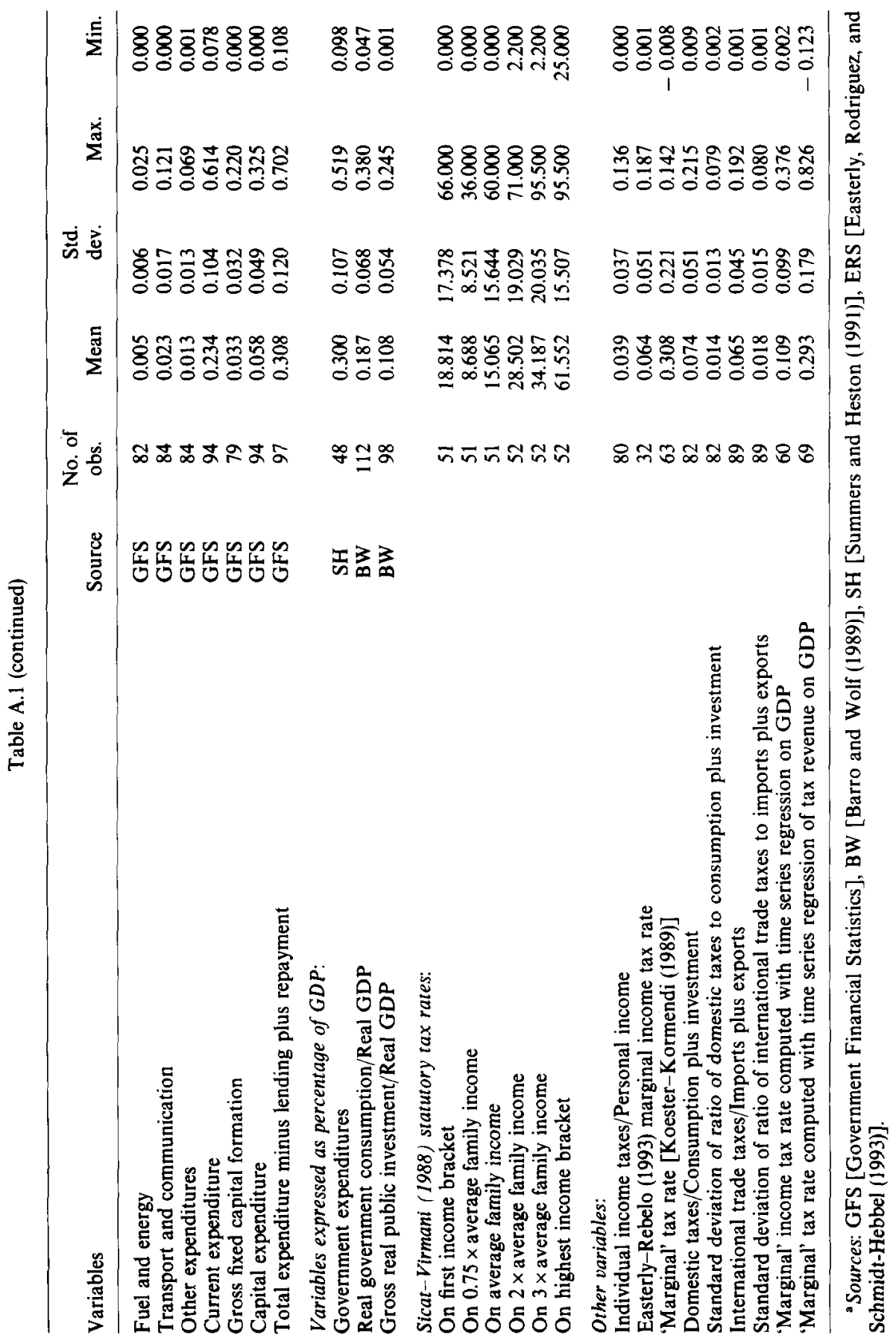




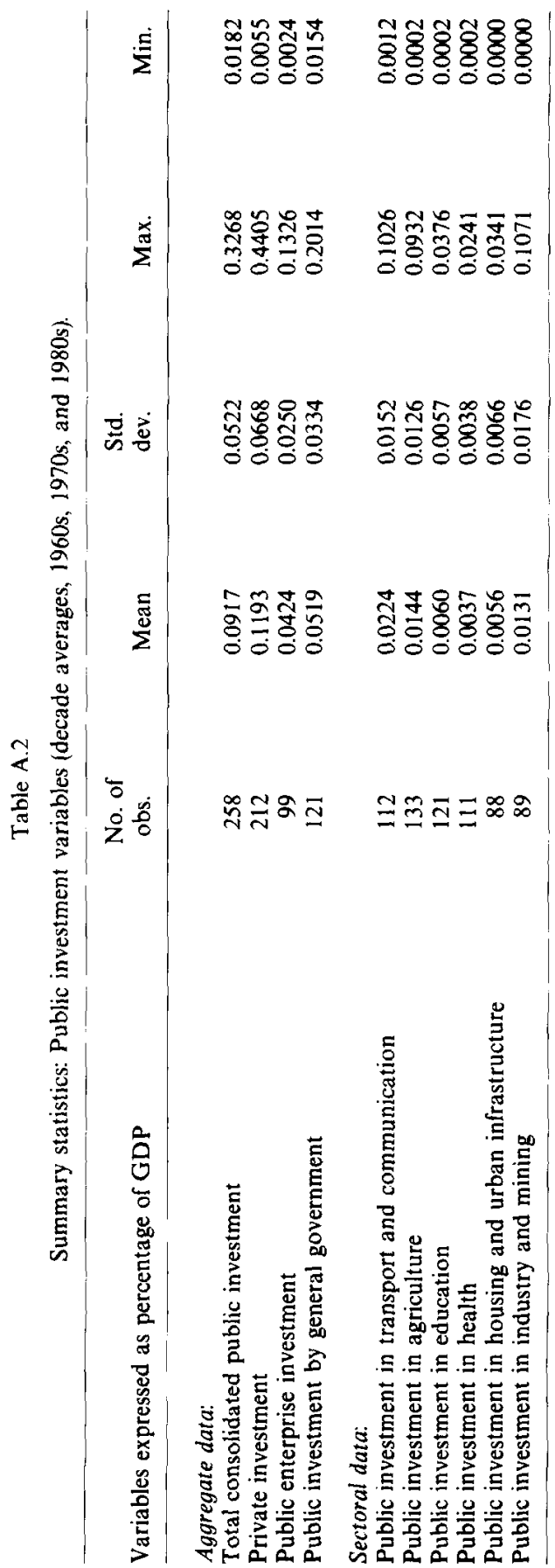




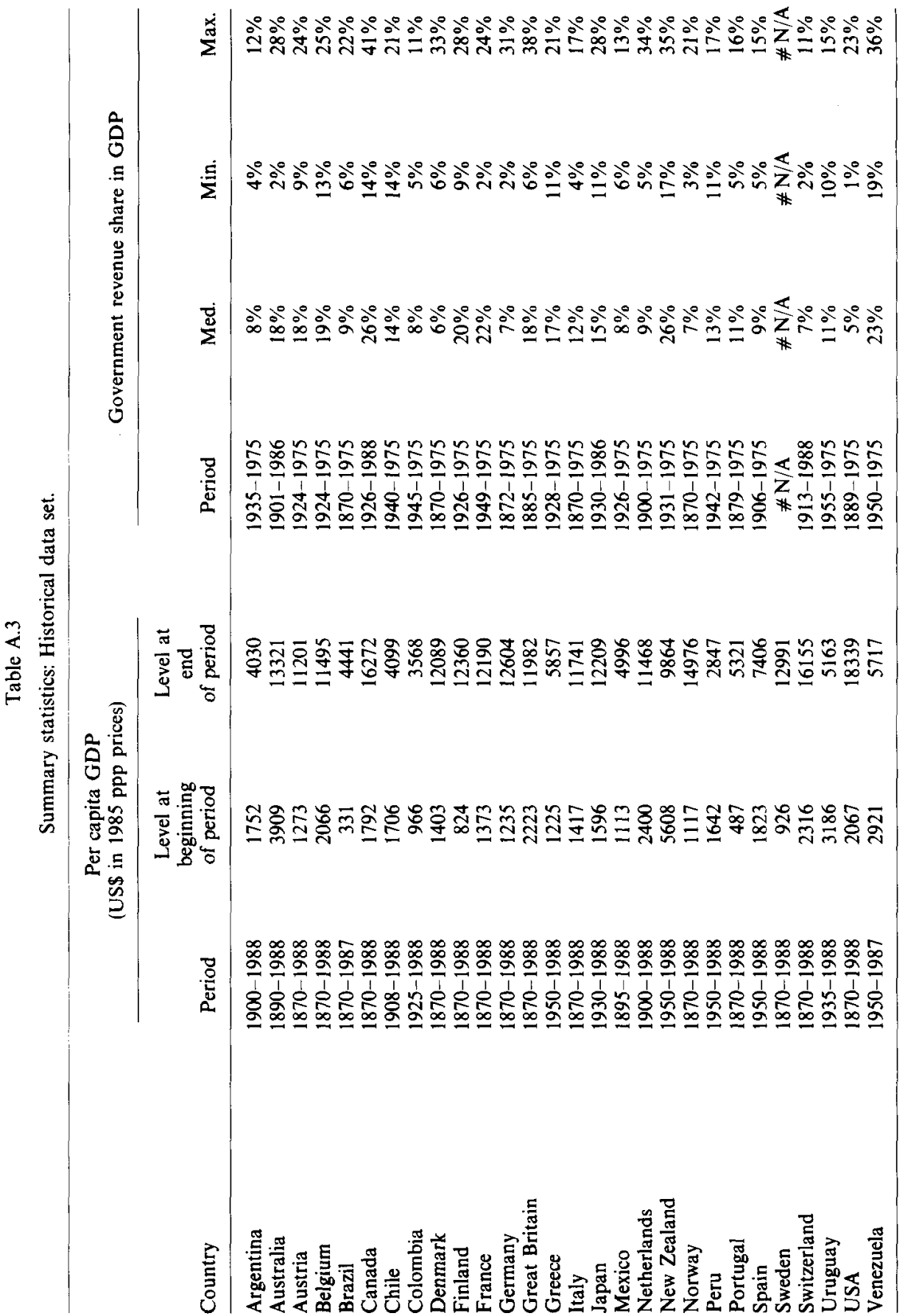




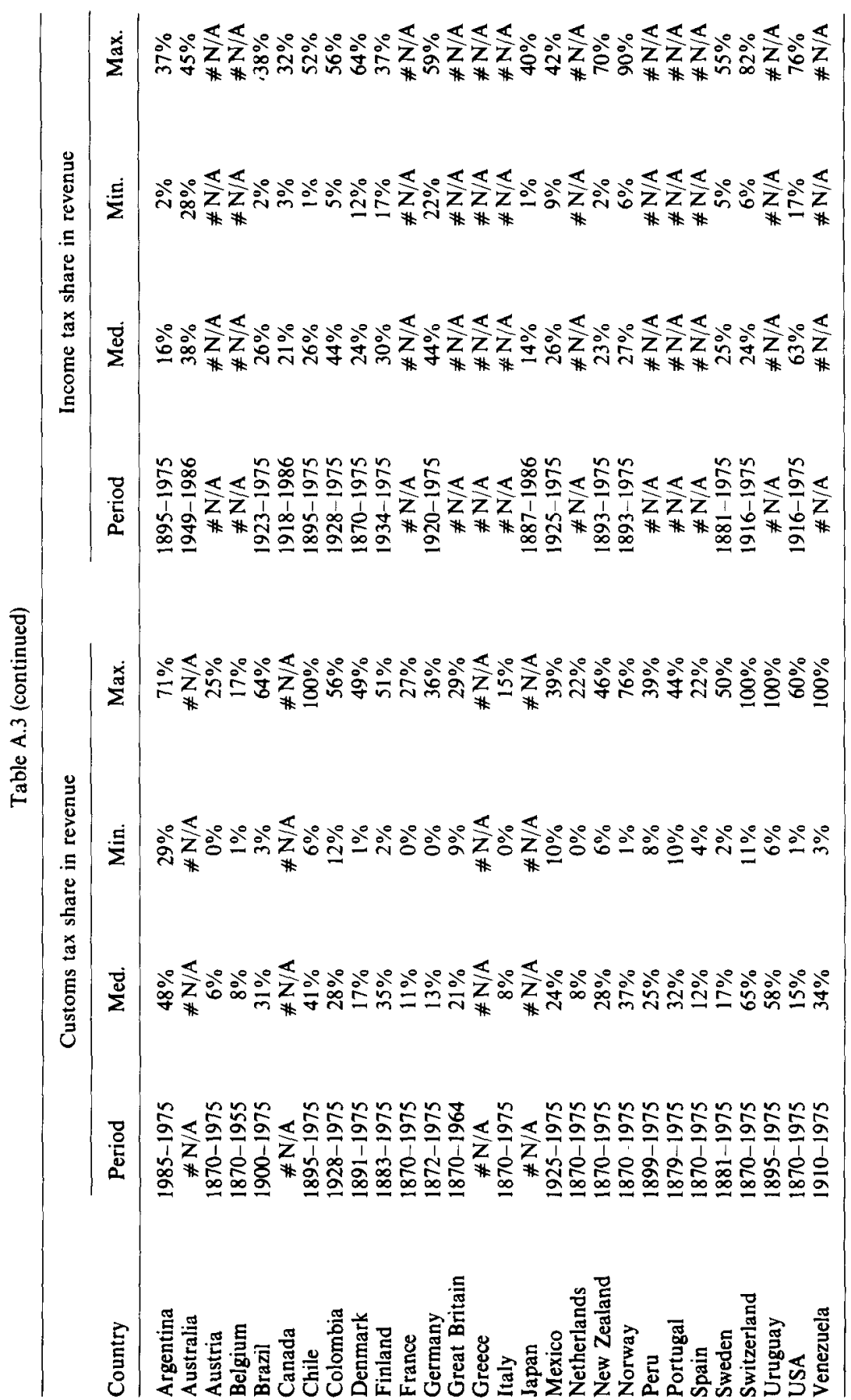




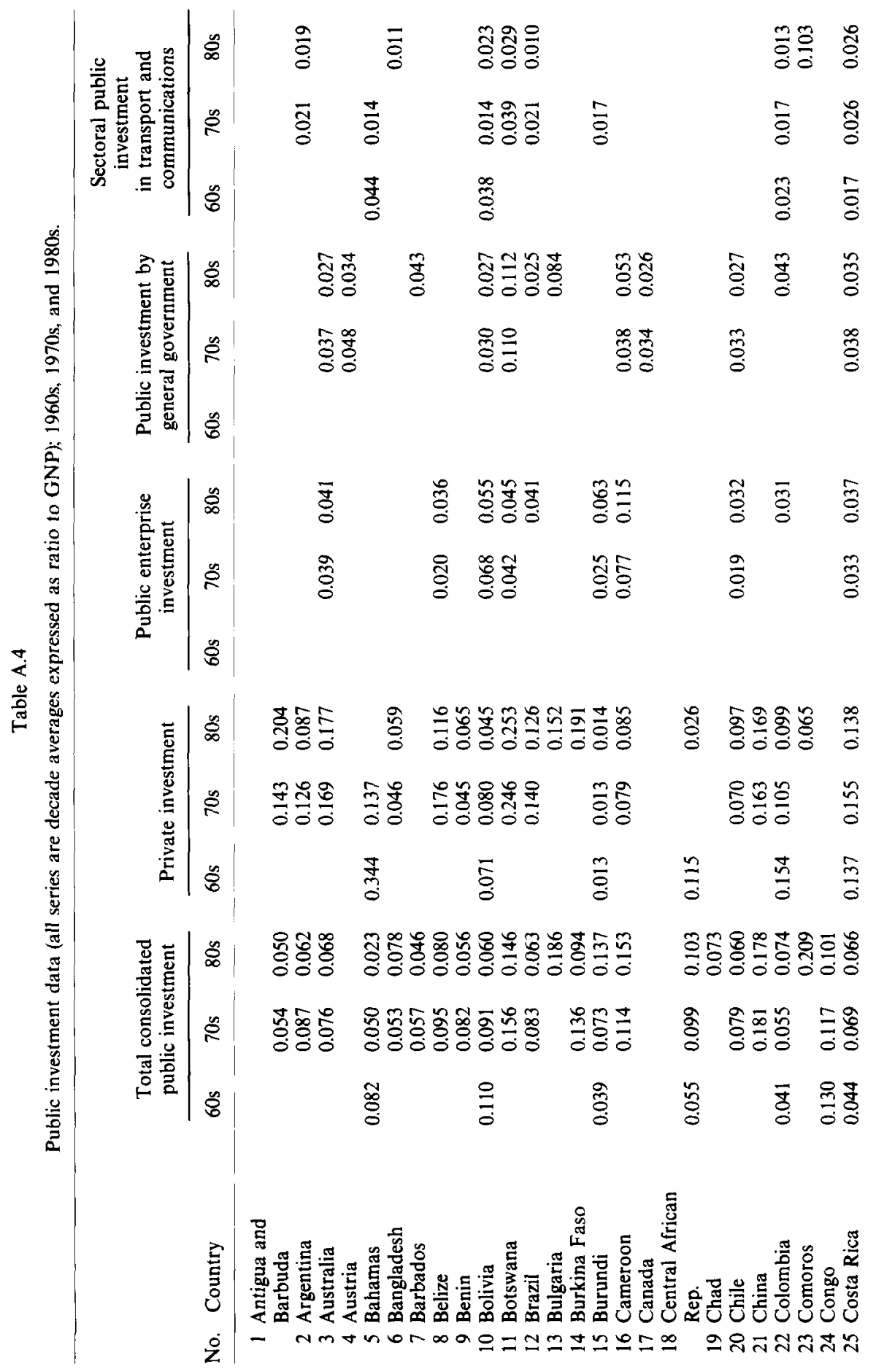




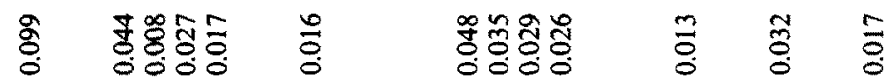

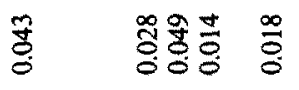

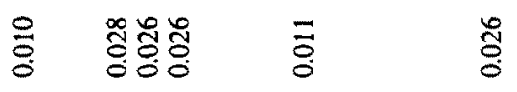
สิธ $\overline{8}$
․ㅠㅇ융융

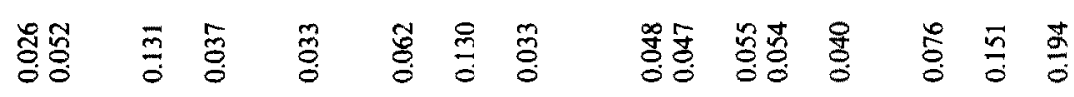

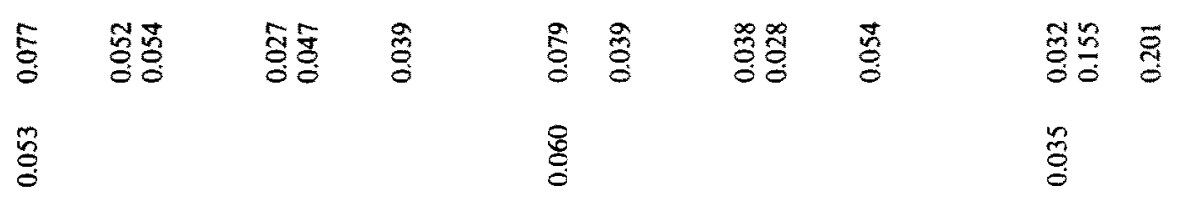
홓ํㅎㅎ융
\&
कृष्ठ்

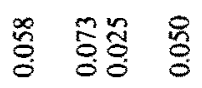

홍 홍긍영

突鱼 路

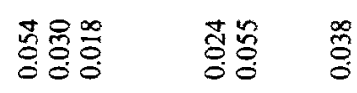

要

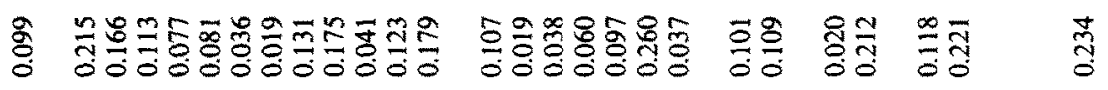

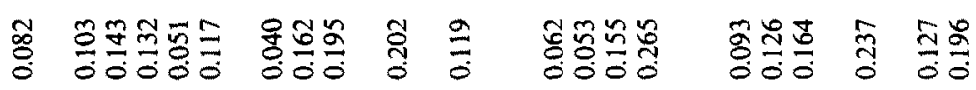

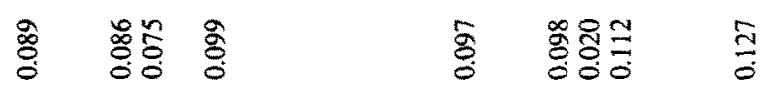

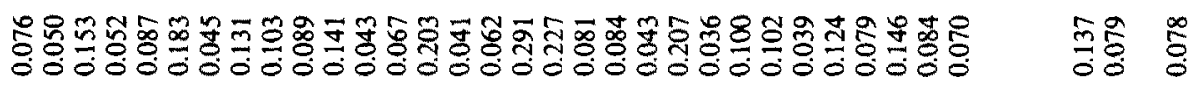

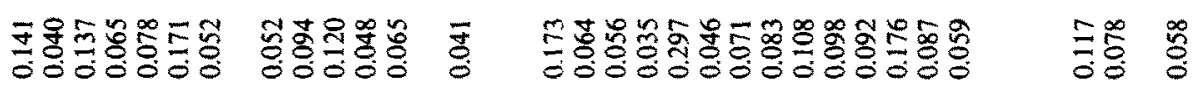

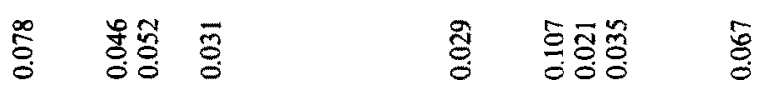

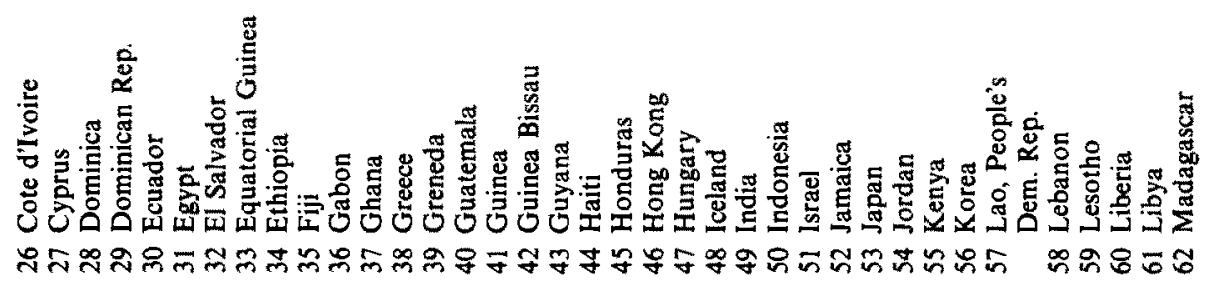




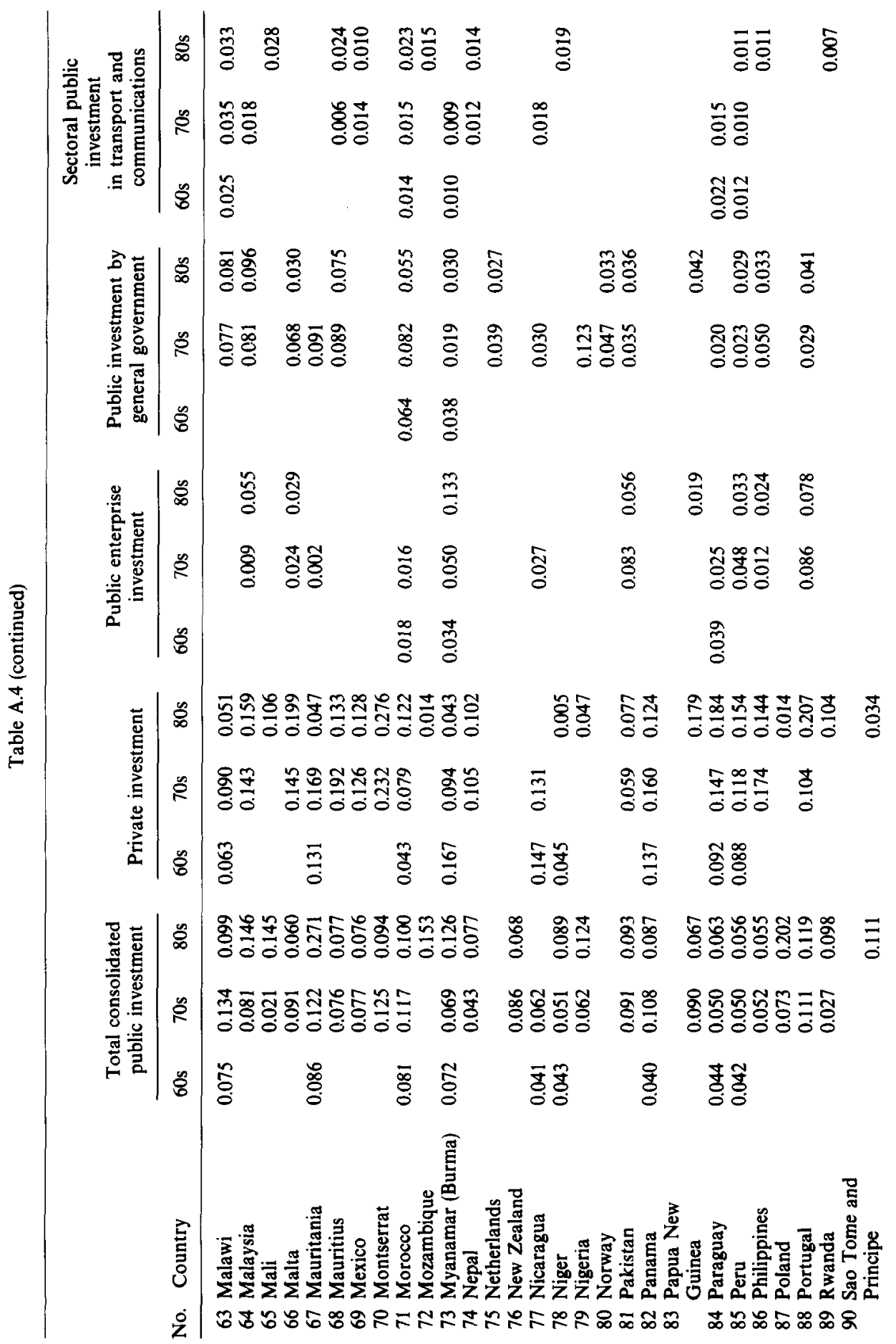




\begin{tabular}{|c|c|c|c|c|}
\hline : & 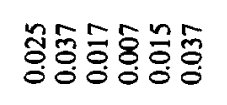 & क्षृ: & छे & $\tilde{\Xi}$ \\
\hline 要产言 & ఫ్ర్రి: & 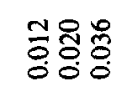 & 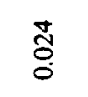 & స్రే \\
\hline ఫ్రి & & ฮิ & $\stackrel{\circ}{\circ}$ & $\bar{s}$ \\
\hline
\end{tabular}

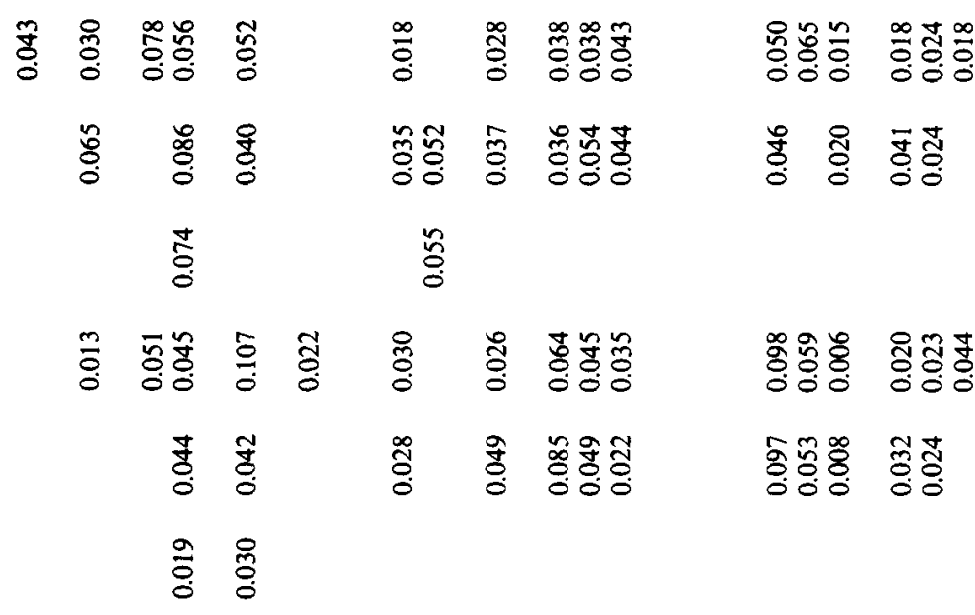

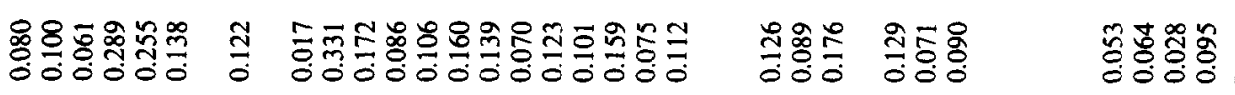

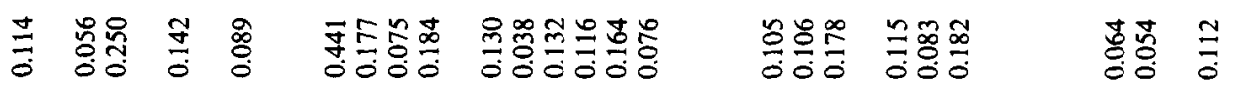

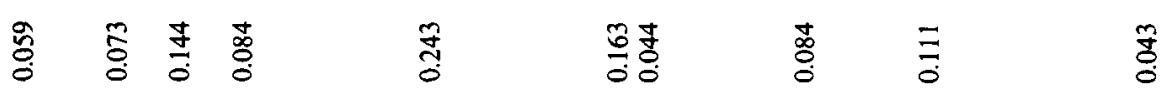

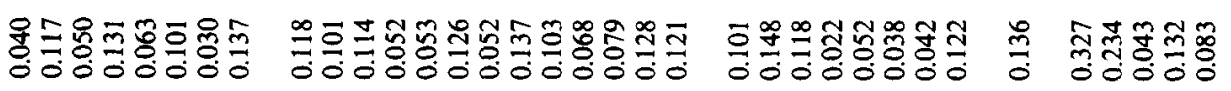

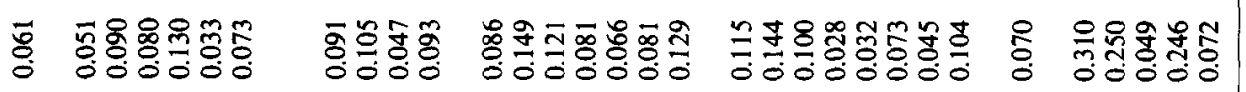

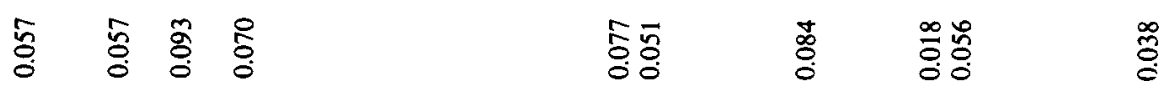

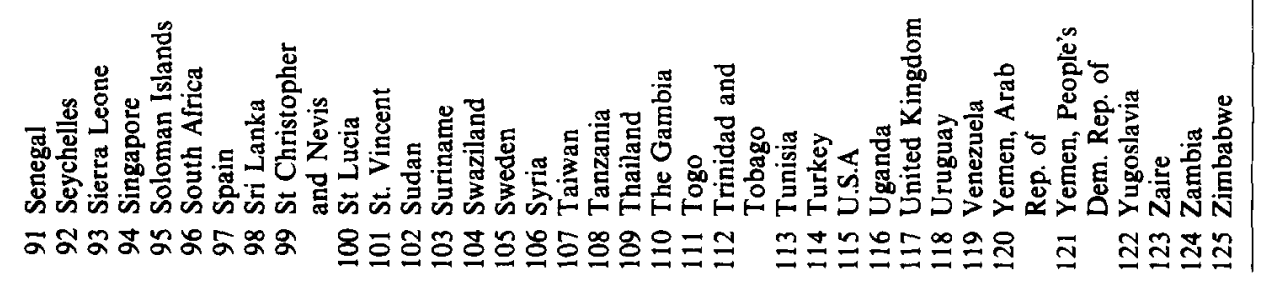




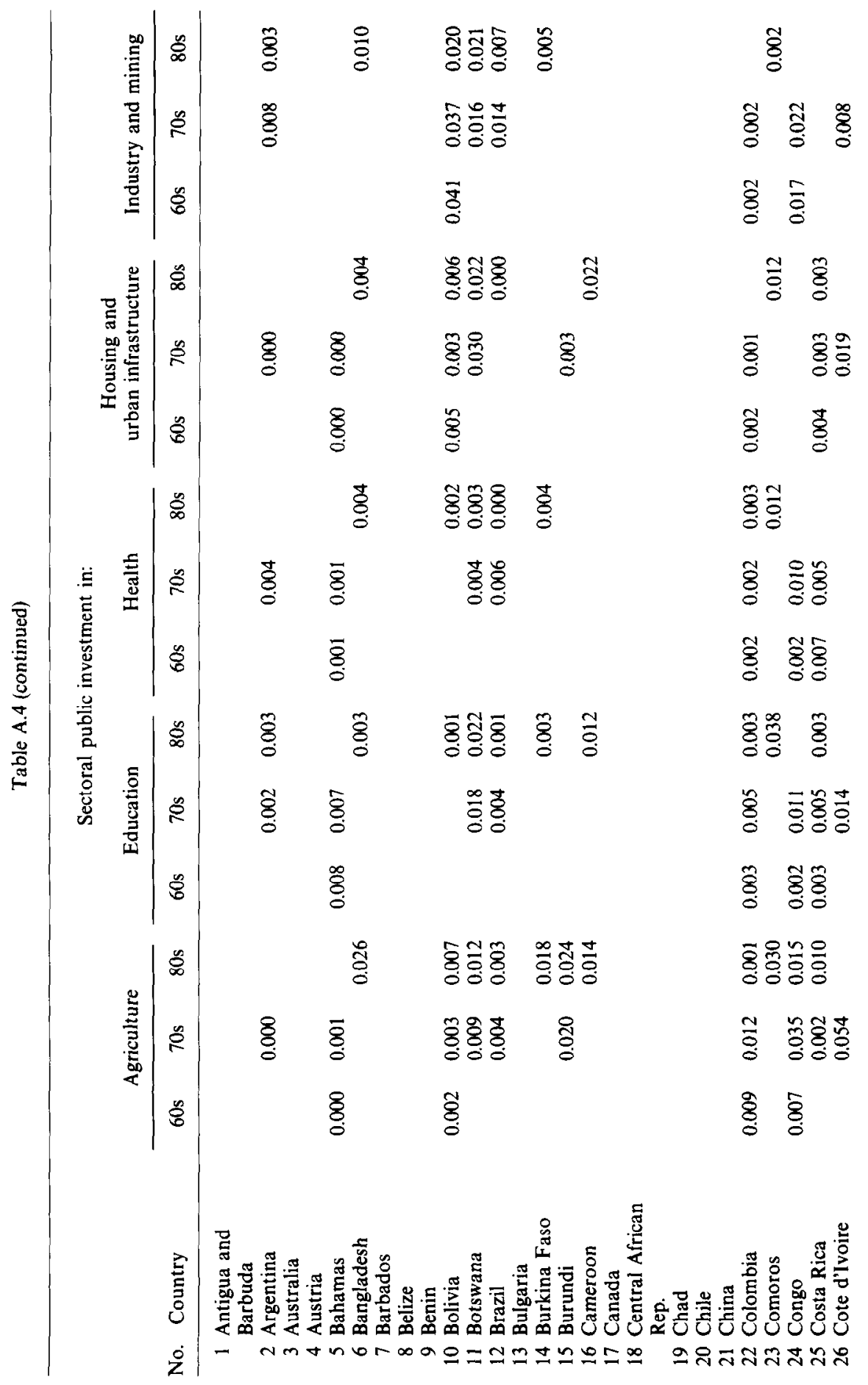




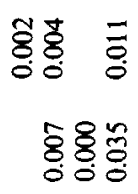

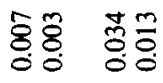

:

容

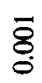

영웅

:

$\S_{0}^{\infty}$

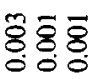

홍 홍종형

항 형 향

8.

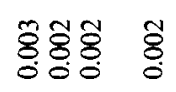

홍 옹

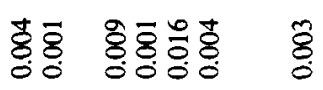

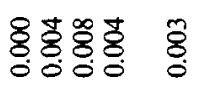

害 密

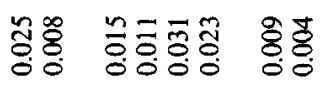

홍홍응응 영 훙

$$
\text { 㗉 }
$$

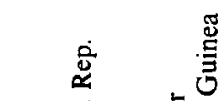

홍

홍 $\bar{c}$

형 $\overline{\bar{c}} \overline{\mathrm{g}} \overline{\mathrm{g}} \overline{\mathrm{g}}$

홍 능
क⿺辶冋

형형

5

$\frac{0}{0}$

突

छั

$\overline{8}$

$\underset{8}{8}$

$\ddot{8}$

$\sum_{0}^{\infty}$

喜 害

8

$\oint_{8}^{m} \quad \stackrel{8}{8}$

8

$\overline{8}$

$\overline{0}$

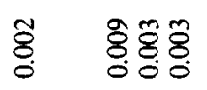

营

$\frac{8}{8}$

$\oint_{0}^{\infty}$

8

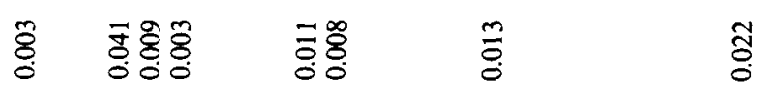

$\oint_{\beta}^{\infty}$

\%

s)

产

言

$\frac{\infty}{8}$

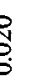
흥

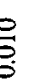

$\bar{s}$

客

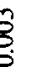

8

홍 총

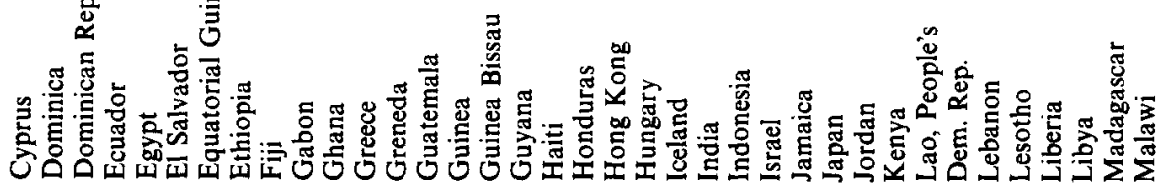

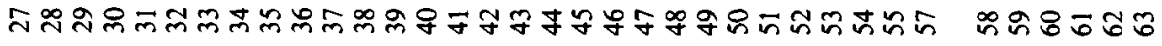




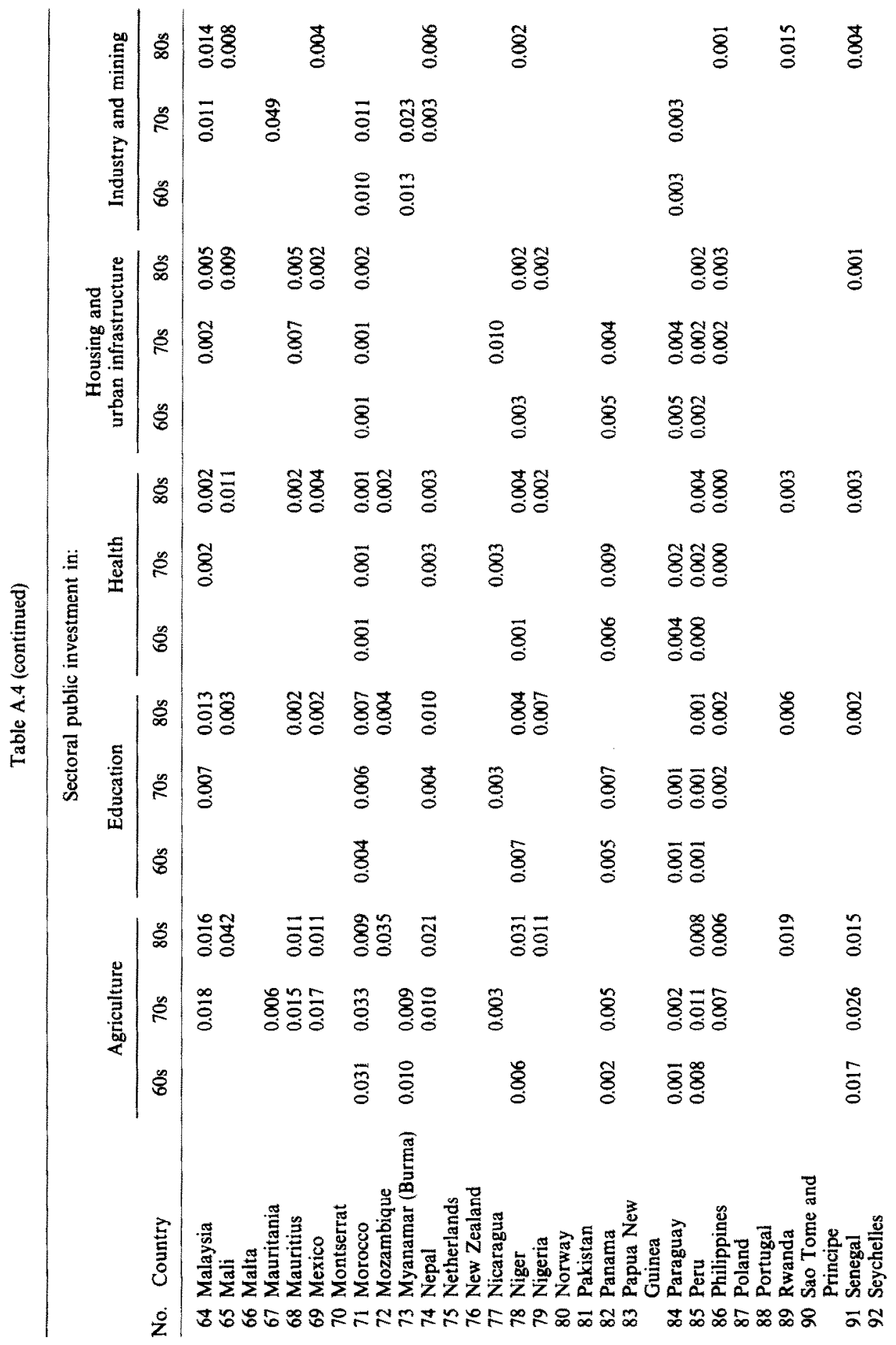




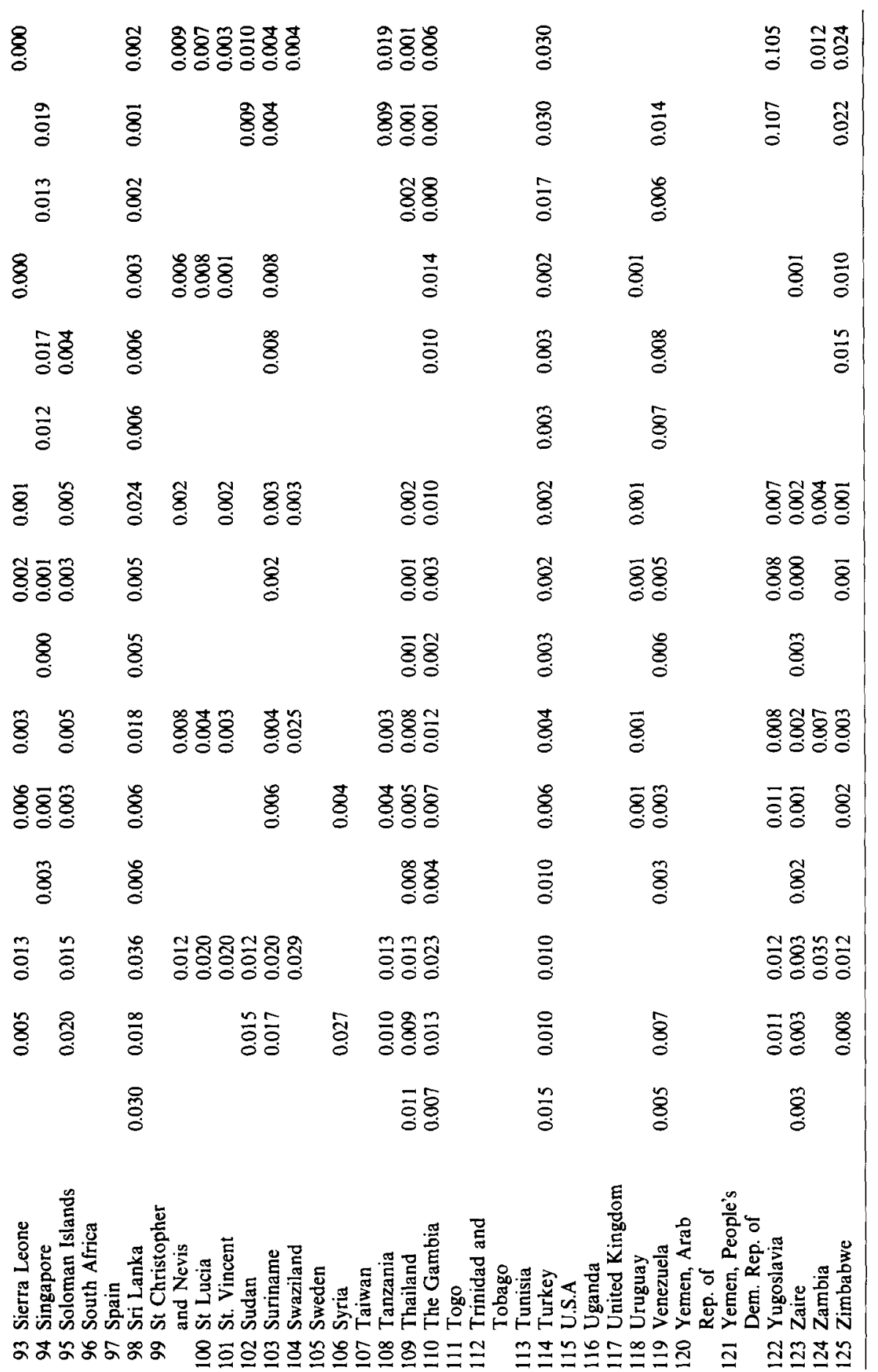




\section{References}

Alesina, A. and D. Rodrick, 1991, Distributive politics and growth, NBER working paper no. 3668.

Alogoskoufis, G. and R. van der Ploeg, 1991, Endogenous growth and overlapping generations, Mimeo. (Birkbeck College, London).

Aschauer, D., 1989, Is public expenditure productive?, Journal of Monetary Economics 23, 177-200.

Auerbach, A. and L. Kotlikoff, 1987, Dynamic fiscal policy (Harvard University Press, Cambridge, MA).

Azariadis, C. and A. Drazen, 1990, Threshold externalities in economic development, Quarterly Journal of Economics 105, 501-526.

Bandyopadhyay, S. and S. Devarajan, 1993, Using project rates of return to inform sector allocation decisions, Mimeo. (World Bank, Washington, DC).

Barro, R., 1990, Government spending in a simple model of endogenous growth, Journal of Political Economy 98, S103-S125.

Barro, R., 1991, Economic growth in a cross section of countries, Quarterly Journal of Economics $106,407-444$.

Barro, R. and C. Sahasakul, 1983, Measuring the marginal tax rate from the individual income tax, Journal of Business 56, 419-452.

Barro, R. and X. Sala-i-Martin, 1992, Convergence, Journal of Political Economy 100, 223-251.

Barro, R. and S. Wolf, 1989, Data appendix for economic growth in a cross-section of countries, Mimeo. (Harvard University, Cambridge, MA).

Becker, G., K. Murphy, and R. Tamura, 1990, Human capital, fertility, and economic growth, Journal of Political Economy 98, S12-S37.

Burgess, R. and N. Stern, 1993, Taxation and development, Journal of Economic Literature 31, 762-830.

Canning, D. and M. Fay, 1993, The effect of infrastructure networks on economic growth, Mimeo. (Columbia University, New York, NY).

Cass, D., 1965, Optimum growth in an aggregative model of capital accumulation, Review of Economic Studies 32, 233-240.

Chamley, C., 1986, Optimal taxation of capital income in general equilibrium with infinite lives, Econometrica 54, 607-622.

Clarke, G., 1992, More evidence on income distribution and growth, Working paper no. 1064 (World Bank, Washington, DC).

Cohen, D. and P. Michel, 1991, Property rights on foreign capital and long run growth, Working paper no. 9106 (CEPREMAP, Paris).

Cukierman, A. and S. Webb, 1993, Political influence on the Central Bank: International evidence, Mimeo. (World Bank, Washington, DC).

Diamond, P., 1965, National debt in a neoclassical growth model, American Economic Review 55, $1125-1150$.

Dunn, D. and A. Pellechio, 1990, Analyzing taxes on business income with the effective tax rate model, Discussion paper no. 79 (World Bank, Washington, DC).

Easterly, W. and S. Rebelo, 1993, Marginal income tax rates and economic growth in developing countries, European Economic Review 37, 409-417.

Easterly, W., C. Rodriguez, and K. Schmidt-Hebbel, eds., 1993, Public sector deficits and macroeconomic performance (Oxford University Press, Oxford) forthcoming.

Easterly, W., M. Kremer, L. Pritchett, and L. Summers, 1993, Good policy or good luck? Country growth performance and temporary shocks, Journal of Monetary Economics, this issue.

Eaton, J., 1981, Fiscal policy, inflation and the accumulation of risky capital, Review of Economic Studies 48, 435-445.

Engen, E. and J. Skinner, 1992, Fiscal policy and growth, NBER working paper no. 4223.

Feldstein, M., 1974, Tax incidence in a growing economy with variable labor supply, Quarterly Journal of Economics 88, 551-573.

Fischer, S., 1993, Macroeconomic factors in growth, Journal of Monetary Economics, this issue.

Garcia-Mila, 1987, Government purchases and real output: An empirical analysis and equilibrium model with public capital, Working paper (Universitat Autonoma, Barcelona).

Grier, K. and G. Tullock, 1989, An empirical analysis of cross-national economic growth, 1951-1980, Journal of Monetary Economics 87, 225-252. 
Holtz-Eakin, D., 1992, Public sector capital and the productivity puzzle, NBER working paper no. 4122.

Jones, L. and R. Manuelli, 1990, A convex model of equilibrium growth: Theory and policy implications, Journal of Political Economy 98, 1008 -1038.

Jones, L., R. Manuelli, and P. Rossi, 1993, Optimal taxation in convex models of equilibrium growth, Journal of Political Economy 101, 485-517.

Judd, K., 1985, Redistributive taxation in a simple perfect foresight model, Journal of Public Economics 28, 59-83.

King, M. and D. Fullerton, 1984, The taxation of income from capital: A comparative study of the United States, the United Kingdom, Sweden, and West Germany (Chicago University Press, Chicago, IL).

King, R. and R. Levine, 1993, Finance and growth: Schumpeter might be right, Quarterly Journal of Economics 108, 717-737.

King, R. and S. Rebelo, 1993, Transitional dynamics and economic growth in the neoclassical model, American Economic Review, forthcoming.

Koester, R. and R. Kormendi, 1989, Taxation, aggregate activity and economic growth: Crosscountry evidence on some supply-side hypotheses, Economic Inquiry 27, 367-386.

Koopmans, T., 1965, On the concept of optimal economic growth, in: The econometric approach to development planning, Pontific Acad. Sci. (North-Holland, Amsterdam) 225-287.

Krzyzaniak, M., 1967, The long run burden of a general tax on profits in a neo-classical world, Public Finance 22, 472-491.

Levine, R. and D. Renelt, 1992, A sensitivity analysis of cross-country growth regressions, American Economic Review 82, 942-963.

Liesner, T., 1989, One hundred years of economic statistics (The Economist Publications, London).

Lucas, R., 1988, On the mechanics of economic development, Journal of Monetary Economics 22, $3-42$.

Lucas, R., 1990, Supply side economics: An analytical review, Oxford Economic Papers 42, 293-316.

Maddison, A., 1982, Phases of capitalistic development (Oxford University Press, Oxford).

Mankiw, G., D. Romer, and D. Weil, 1992, A contribution to the empirics of economic growth, Quarterly Journal of Economics 107, 407-437.

Mitchell, B.R., 1978, European historical statistics, 1750-1970 (Columbia University Press, New York, NY).

Mitchell, B.R., 1982, International historical statistics: Asia and Africa (New York University Press, New York, NY).

Mitchell, B.R., 1983, Historical statistics: The Americas and Australasia (Gale Rescarch Co., Detroit, MI).

Persson, T. and G. Tabellini, 1991, Is inequality harmful for growth? Theory and evidence, NBER working paper no. 3599.

Pfeffermann, G. and A. Madarassy, 1991, Trends in private investment in thirty developed countries, International Finance Corporation discussion paper no. 6 (World Bank, Washington, DC).

Plosser, C., 1993, The search for growth in: Federal Reserve of Kansas City symposium series, Policies for long run growth, 57-86 (Kansas City, MO).

Ram, R., 1987, Wagner's hypothesis in time series and cross section perspectives: Evidence from 'real' data for 115 countries, Review of Economics and Statistics, 194-204.

Rebelo, S., 1991, Long run policy analysis and long run growth, Journal of Political Economy 99, $500-521$.

Rivera-Batiz, L. and P. Romer, 1991, International trade with endogenous technical change, European Economic Review 35, 971-1001.

Romer, P., 1986, Increasing returns and long run growth, Journal of Political Economy 94, $1002-1037$.

Sandford, C., M. Godwin, and P. Hardwick, 1989, Administrative and compliance costs of taxation (Fiscal Publications, Bath).

Sato, K., 1967, Taxation and neoclassical growth, Public Finance 22, 346-370.

Sicat, G. and A. Virmani, 1988, Personal income taxes in developing countries. The World Bank Economic Review 1, 123-138.

Solow, R., 1956, A contribution to the theory of economic growth, Quarterly Journal of Economics $70,65-94$. 
Stokey, N. and S. Rebelo, 1993, Growth effects of flat tax rates, Working paper (University of Chicago, Chicago, IL).

Summers, L., 1981, Capital taxation and accumulation in a life-cycle growth model, American Economic Review 71, 533-544.

Summers, R. and A. Heston, 1991, The Penn world table (Mark 5): An expanded set of international comparisons, 1950-1988, Quarterly Journal of Economics 2, 327-368.

Tanzi, V., 1987, Quantitative characteristics of the tax systems of developing countries, in: D. Newbery and N. Stern, The theory of taxation for developing countries (Oxford University Press, Oxford) 205-241.

Tanzi, V., 1992, Structural factors and tax revenue in developing countries: A decade of evidence, in: I. Goldin and L. A. Winters, Open economies, structural adjustment and agriculture (CEPR and OECD, Paris) 267-285.

Vaillancourt, F., 1989, The administrative and compliance costs of personal income taxes and payroll taxes (Canadian Tax Foundation, Toronto).

Wallis, J., R. Sylla, and J. Legler, 1993, Taxation and regulation in nineteen century America: With particular attention to banks, Mimeo. (New York University, New York, NY).

Watson, M., 1992, A note on estimating deterministic trends in the presence of serially correlated errors, Working paper (Northwestern University, Evanston, IL).

World Bank, 1991, World development report: Supplementary data, Mimeo. (World Bank, Washington, DC).

White, H., 1980, A heteroskedasticity-consistent covariance matrix estimator and a direct test for heteroskedasticity, Econometrica 48, 817-838. 